Review

\title{
Fetal High-Density Lipoproteins: Current Knowledge on Particle Metabolism, Composition and Function in Health and Disease
}

\author{
Julia T. Stadler ${ }^{1, *(\mathbb{D})}$, Christian Wadsack ${ }^{2}(\mathbb{D})$ and Gunther Marsche ${ }^{1, *(\mathbb{D})}$ \\ 1 Division of Pharmacology, Otto Loewi Research Center, Medical University of Graz, Universitätsplatz 4, \\ 8010 Graz, Austria \\ 2 Department of Obstetrics and Gynecology, Medical University of Graz, Auenbruggerplatz 14, \\ 8036 Graz, Austria; christian.wadsack@medunigraz.at \\ * Correspondence: julia.stadler@medunigraz.at (J.T.S.); gunther.marsche@medunigraz.at (G.M.); \\ Tel.: +43-316-385-74115 (J.T.S.); +43-316-385-74128 (G.M.)
}

Citation: Stadler, J.T.; Wadsack, C.; Marsche, G. Fetal High-Density Lipoproteins: Current Knowledge on Particle Metabolism, Composition and Function in Health and Disease. Biomedicines 2021, 9, 349. https:// doi.org/10.3390/biomedicines9040349

Academic Editors: Joan Carles Escolà-Gil and Josep Julve

Received: 4 March 2021

Accepted: 25 March 2021

Published: 30 March 2021

Publisher's Note: MDPI stays neutral with regard to jurisdictional claims in published maps and institutional affiliations.

Copyright: (C) 2021 by the authors. Licensee MDPI, Basel, Switzerland. This article is an open access article distributed under the terms and conditions of the Creative Commons Attribution (CC BY) license (https:/ / creativecommons.org/licenses/by/ $4.0 /)$.

\begin{abstract}
Cholesterol and other lipids carried by lipoproteins play an indispensable role in fetal development. Recent evidence suggests that maternally derived high-density lipoprotein (HDL) differs from fetal HDL with respect to its proteome, size, and function. Compared to the HDL of adults, fetal HDL is the major carrier of cholesterol and has a unique composition that implies other physiological functions. Fetal HDL is enriched in apolipoprotein E, which binds with high affinity to the low-density lipoprotein receptor. Thus, it appears that a primary function of fetal HDL is the transport of cholesterol to tissues as is accomplished by low-density lipoproteins in adults. The fetal HDL-associated bioactive sphingolipid sphingosine-1-phosphate shows strong vasoprotective effects at the fetoplacental vasculature. Moreover, lipoprotein-associated phospholipase A2 carried by fetal-HDL exerts anti-oxidative and athero-protective functions on the fetoplacental endothelium. Notably, the mass and activity of HDL-associated paraoxonase 1 are about 5 -fold lower in the fetus, accompanied by an attenuation of anti-oxidative activity of fetal HDL. Cholesteryl ester transfer protein activity is reduced in fetal circulation despite similar amounts of the enzyme in maternal and fetal serum. This review summarizes the current knowledge on fetal HDL as a potential vasoprotective lipoprotein during fetal development. We also provide an overview of whether and how the protective functionalities of HDL are impaired in pregnancy-related syndromes such as pre-eclampsia or gestational diabetes mellitus.
\end{abstract}

Keywords: HDL; fetal development; pregnancy; sphingosine-1-phosphate; LpPLA 2 ; gestational diabetes mellitus; preeclampsia

\section{Introduction}

Cholesterol is an essential constituent in fetal development [1,2]. It has long been assumed that the fetus synthesizes most of its cholesterol requirements for growth de novo. However, in vitro and in vivo studies have shown that maternal circulating cholesterol can influence fetal metabolism [3,4]. Maternal dyslipidemia which is reflected either by an excess-, or also by limited cholesterol in the fetal circulation can affect fetal growth and health [5]. Maternally derived lipoproteins carrying cholesterol bind to their respective receptors expressed on the syncytiotrophoblast of the placental villi [6-8]. After cholesterol is taken up into the syncytium it is transported across the placental stroma to the fetal side. The exact transport mechanism is still elusive. At the endothelium of the fetoplacental vasculature, cholesterol is then transported via ATP-binding cassette G1 (ABCG1) or ATP-binding cassette A1 (ABCA1) to acceptors such as fetal HDL or lipid-poor apolipoproteins $[4,9]$. Interestingly, cholesterol is mainly carried by HDL in the fetal circulation, whereas in adults the majority of cholesterol is carried by low-density lipoproteins (LDL). 
Fetal HDL shows a unique composition and is suggested to exert different functions as in adults [10]. The current review focuses on the role of lipids carried by HDL in fetal circulation and the importance of exogenous cholesterol supply by the mother. Here, we summarize the proteomic composition of fetal HDL and highlight conspicuous changes compared to adult HDL. Further, we discuss the relationship of fetal HDL and sphingosine1-phosphate (S1P) and the importance of S1P signaling at the fetoplacental vasculature in maintaining vascular integrity. Finally, the impact of pregnancy-associated disorders, such as preeclampsia (PE) and gestational diabetes mellitus (GDM) on HDL metabolism and function is comprehensively discussed.

\section{Changes in Maternal Lipid Metabolism during a Normal Pregnancy}

During pregnancy, multiple physiological changes occur that strongly influence maternal lipid metabolism. In the first two trimesters of pregnancy, maternal lipid metabolism is primarily anabolic and characterized by several factors that increase lipid accumulation in maternal tissues in preparation for the exponential increase in fetal energy requirements later in pregnancy [11,12]. These factors include maternal hyperphagia, to increase the availability of exogenous metabolic substrates $[11,13]$ and an increase in insulin sensitivity which results in increased lipogenesis [14]. In the anabolic phase, hormonal and metabolic changes occur such as cortisol and leptin stimulation, and increased progesterone levels contribute to the accumulation of maternal fat depot [14].

During the last trimester of pregnancy, the lipid metabolism changes to the catabolic phase with a decline of fat accumulation [15]. This phase is characterized by increased lipolysis and mobilization of triglycerides from adipocytes. Furthermore, these changes are accompanied by a decrease of lipoprotein lipase (LPL) activity, leading to inefficient clearance of triglyceride-rich lipoproteins [16,17]. Maternal hyperlipidemia in late pregnancy coincides with changes in insulin sensitivity, which consistently decreases during this phase [18]. This decline is mediated by several factors, including increased levels of estrogen, placental lactogen, and progesterone [19].

During pregnancy, the lipid profile of mothers shows a 2.5-fold increase in verylow-density lipoprotein (VLDL) triglycerides and cholesterol and a 1.6-fold increase in LDL-cholesterol compared to non-pregnant women [20]. Plasma levels of VLDL and LDL steadily increase during gestation, while HDL levels show the highest rise in midgestation ( $45 \%$ above baseline) followed by a decline at term to about 15\% [20]. HDL subclass analysis showed that levels of the triglyceride-rich HDL2 rise, while the smaller, lipid-poor HDL3 becomes less abundant [17]. These well-described alterations in lipoproteins, which are responsible for respective changes in maternal lipid profile during gestation are explained by several mechanisms: The increase of insulin resistance in late pregnancy mediates the elevated lipolytic activity in adipocytes, resulting in increased accessibility of substrates for triglyceride production in the liver [21,22]. Together with the decreased activity of LPL [17] and the stimulative effect of estrogen [23], these metabolic adaptions lead to an increased hepatic production of VLDL. The increased activity of the cholesteryl-ester transfer protein (CETP), which mediates the transfer of triglycerides on lipoproteins with higher density, contributes to the enrichment of triglycerides in HDL and LDL [17,24]. Another factor, contributing to the increase of triglyceride-rich HDL, is the reduced hepatic lipase activity, which reduces the clearance of HDL2 to smaller HDL3 [25].

Maternal hyperlipidemia during pregnancy is a prerequisite for delivering sufficient lipids of lipoproteins to the fetus. However, reduced or too high cholesterol supply to the fetus may lead to long-term consequences to the fetus [26].

\section{Importance of Cholesterol in Fetal Development}

Cholesterol is an essential constituent in embryonic and fetal development. It is a crucial component of cell membranes by defining fluidity and permeability. Further, cholesterol is an integral part of membrane microdomains, such as lipid rafts, which are essential for plasma-membrane-dependent signaling cascades. Cholesterol is a precursor 
of steroid hormones, including progesterone, and of its oxidative derivate oxysterol, which plays an important role in several metabolic processes [27].

The high requirements of cholesterol for the developing fetus have been described with 1.5-2.0 g of accumulated cholesterol per kg of added tissue [28]. The endogenous cholesterol originates from either de novo biosynthesis or hydrolysis of intracellular cholesteryl deposits by cholesterol esterases [29]. The fetus additionally possesses the capability to cover its demand of cholesterol from exogenous deposits. Yolk sac in early pregnancy and later the placenta has the same property to store maternally derived cholesterol [13]. The fact that the fetus does not rely on its own endogenously cholesterol was demonstrated in fetuses with the Smith-Lemli-Opitz syndrome, a condition with an inborn error of cholesterol synthesis. Fetuses affected by this syndrome harbor a nonsense mutation in the 7-dehydrocholesterol reductase, an enzyme that catalyzes the conversion of 7-dehydrocholesterol to cholesterol. Fetuses with this congenital condition are capable of developing to term, thereby demonstrating that maternal cholesterol needs to be transported across the placenta to maintain the demands of the fetus $[13,30]$.

The human placenta is a unique organ, which is composed of several specialized cell types and mediates many metabolic exchange mechanisms between mother and fetus. To fulfill the demands of the fetus, nutrients and oxygen diffuse from maternal to fetal circulation by crossing directly into different cell layers. The first physical barrier, which limits nutrient transfer across the placenta is build up by the syncytiotrophoblast, a layer of multinucleated trophoblasts localized by the microvillous and basal membrane faced to the maternal and fetal side, respectively [31,32].

The first step of cholesterol transport from the mother to the fetus is the uptake on the apical, maternal side. Human placental trophoblasts express lipoprotein receptors such as scavenger receptor BI (SR-BI), LDL-receptor (LDL-R), and LDL receptor-related protein 1 (LRP1) (Figure 1) [4,6-8]. These receptors mediate the uptake of cholesterol and cholesteryl-esters from maternally derived lipoproteins [29,33]. After receptor-mediated endocytosis, the lipoprotein-associated cholesteryl-esters are intracellularly hydrolyzed [4]. Via Niemann-Pick $\mathrm{C} 1$ and/or other sparsely described cholesterol transporter proteins, free cholesterol is trafficked across the cell to membranes or metabolically active pools [4,34]. SR-BI mediates the selective uptake of cholesteryl-esters primarily from HDL, which are hydrolyzed by cytosolic cholesterol esterases and transported by potential carrier proteins to the basal membrane [4]. However, the exact pathway of transcellular cholesterol transport is still not known, but several transporters are thought to be involved, such as Niemann-Pick C1, Niemann-Pick C1-like protein 1, sterol carrier protein-x/2 and ABCA2. All these receptors are expressed in the human placenta [35]. To enter the fetal circulation, placental cholesterol needs to cross the endothelium at the fetoplacental vasculature. By using endothelial cells isolated from human term placentas, a study demonstrated efflux/secretion of exogenous cholesterol through ABCA1 and ABCG1 [9]. Acceptors of cholesterol in the cord blood are poorly lipidated apolipoprotein (apo) A-I (the major HDL associated apolipoprotein in adults), apoE, and HDL, with apoE-enriched HDL, was shown to be most efficient $[9,35]$.

Maternally supplied cholesterol appears to be of great importance for fetal growth. Although there is no direct link between maternal and fetal lipoprotein metabolism, maternal serum cholesterol levels during pregnancy are directly related to infant birth weight. Low maternal serum cholesterol levels during pregnancy appear to increase the risk of microencephaly, while high maternal cholesterol levels promote the early incidence of atherogenicity $[13,36]$. Various further studies demonstrated a link between very high maternal cholesterol levels with prematurity and impaired fetal growth [37-39]. Dysregulated maternal cholesterol homeostasis during pregnancy has also been associated with disorders such as pregnancy-induced hypertension and preeclampsia [37,40,41].

Concluding, cholesterol plays an essential role in human fetal development and maternal hypocholesterolemia, as well as hypercholesterolemia, can affect fetal health and growth. 


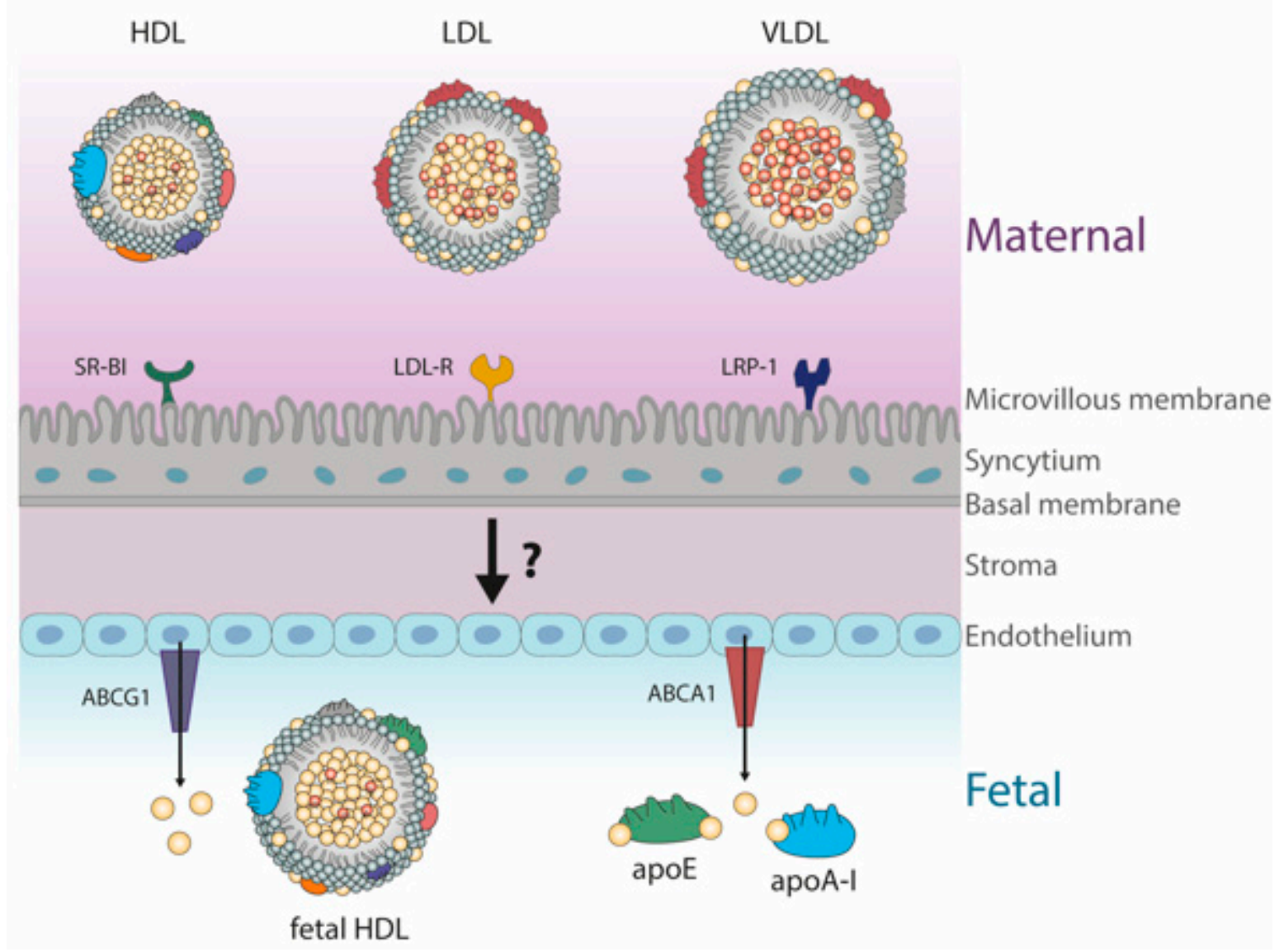

Figure 1. Described routes how maternal cholesterol is transported across the human placenta. First, maternally derived lipoproteins interact with respective receptors at the microvillous membrane of the syncytium. After uptake of cholesterol in the syncytium, it is secreted/effluxed to lipid-poor acceptor apolipoproteins of fetal HDL. How stroma transfers cholesterol to the fetoplacental endothelium remains elusive. High-density lipoprotein; SR-BI; scavenger receptor BI; LDL, low-density lipoprotein; VLDL, very-low-density lipoprotein; LDL-R, low-density lipoprotein receptor; LRP-1, LDL receptor-related protein 1; ABCA1, ATP-binding cassette A1; ABCG1, ATP-binding cassette G1.

\section{HDL Composition}

HDLs are a group of highly heterogeneous lipoproteins, which are considered to have a high cardiovascular protective potential [42-44]. The heterogeneity of these particles depends on their size, shape, and compositional structure [45].

The major apolipoprotein in HDL is apoA-I, which accounts for around $70 \%$ of the total protein amount [46]. The second major apolipoprotein is apoA-II, which represents approximately $15-20 \%$ of total protein content [47]. The residual protein mass of HDL is composed of minor apolipoproteins, such as apoCs and apoA-IV, having an important enzyme regulatory function. ApoM is another crucial protein component on HDL, as it binds hydrophobic molecules, primarily sphingosine-1-phosphate (S1P) [48,49]. ApoE, apoD, apoF, apoJ, and apoL-I are further distinctly identified proteins on HDL whose exact roles have partly been identified. In addition, serum amyloid A (SAA), which is predominantly produced by the liver in the acute phase after an inflammatory stimulus, is mainly carried by HDL [50]. Furthermore, several enzymes are associated with HDL, including paraoxonase 1 (PON1), which has anti-inflammatory and antioxidative properties [51]. Direct binding of the enzyme to apoA-I on HDL stabilizes the protein and also stimulates PON1 lactonase activity [52]. Other HDL-associated enzymes are the lipoprotein-associated phospholipase A2 (LpPLA2) and lecithin-cholesterol-acyltransferase (LCAT). Addition- 
ally, enzymes with lipid transfer activity are important in HDL metabolism, including cholesterol ester transfer protein (CETP) and phospholipid transfer protein.

The most abundant lipids in HDL are phospholipids. Phospholipids and sphingolipids make up about $40-60 \%$ of the HDL lipidome, whereas cholesteryl-ester (30-40\%), free cholesterol $(5-10 \%)$, and triglycerides $(5-12 \%)$ are not as prominent [53]. Like HDLassociated proteins, lipids of HDL also fulfill important structural functions. The ability of HDL to mediate cholesterol efflux is markedly modulated by the characteristics of its surface lipids. Therefore, phospholipids, which compose the surface lipid monolayer of HDL are an important determinant of its ability to accept cholesterol [53]. Moreover, both, the phospholipid content $[53,54]$ and lysophospholipid content of HDL [55-58] markedly affect its anti-inflammatory properties. Sphingosine-1-phosphate (S1P) plays an important role in maintaining vascular homeostasis, which will be discussed in more detail in 7.2. Altogether, a total of 200 lipids and 80 proteins make up the diversity of different HDL subclasses [59-61].

\section{HDL Functionality}

\subsection{Cholesterol Efflux Capacity}

The best-studied property of HDL, which is also considered as the most clinically relevant atheroprotective function of HDL, is its ability to promote reverse cholesterol transport [62]. The uptake of excessive and accumulated cholesterol from peripheral cells is the first step of reverse cholesterol transport to the liver for catabolism. Given the heterogeneity of HDL particles in terms of structure and lipidomic/proteomic composition, steady-state HDL-cholesterol (HDL-C) levels suffer from the limitations inherent in their mass-based and static measurement. As a snapshot of the steady-state cholesterol pool, HDL-cholesterol levels do not provide direct information on the rate of cholesterol flux from vascular macrophages to the liver, which is influenced by many factors beyond the mass of HDL-C. Recent evidence clearly suggests that the cholesterol efflux capacity of HDL better reflects cardiovascular disease risk than HDL-C [63,64].

The reverse cholesterol transport starts with the release of lipid poor apoA-I from the liver and intestine, which circulates to peripheral cells to take up excess cholesterol, forming nascent HDL. ApoA-I is preferentially lipidated via ABCA1 [65], while cholesterol efflux to larger HDL subclasses is stimulated by ABCG1 [66,67]. Collectively, cholesterol can be actively transferred by SR-BI, ABCA1, and ABCG1, but also via passive diffusion [68-70]. After absorption from cells, cholesterol is esterified, catalyzed by LCAT, and large and mature HDL is formed. The HDL-associated cholesteryl-esters can be further transferred to LDL/VLDL by CETP. Thus, the transport of cholesterol from peripheral cells to the liver occurs via two pathways: Direct uptake by SR-BI and indirectly through HDL-LDL/VLDL interactions [71]. Reaching the liver, cholesteryl-esters are hydrolyzed and free cholesterol is either converted into bile acids, reused for the production of VLDL, or transferred by ABCG5/G8 into the bile.

\subsection{Anti-Inflammatory and Antioxidative Capacities}

Circulating HDL cholesterol concentrations do not provide information about the antiinflammatory, antioxidant, antithrombotic, and endothelial function-promoting activities of HDL. In addition to its important role in reverse cholesterol transport, HDL can inhibit the transmigration of monocytes through endothelial and smooth muscle cell co-cultures [72]. HDL inhibits the expression of adhesion molecules, including vascular cell adhesion molecule, intercellular cell adhesion molecule, and E-selectin [73-75]. Through modulation of NF-KB and PPAR gamma, HDL further decreases the production of chemokines and chemokine receptors in vivo and in vitro [76]. Because of these properties, HDL diminishes the recruitment of monocytes, lymphocytes, and basophils to the vascular endothelium, thus slowing downstream processes of inflammatory response.

In addition to its numerous anti-inflammatory effects, HDL also possesses antioxidative properties. HDL protects LDL and other lipoproteins from oxidative damage 
induced by several oxidants, thereby reducing atherogenicity. ApoA-I plays a crucial role in the anti-oxidative capacity of HDL through the reduction of lipid hydroperoxides by their methionine residues [77,78]. The enzyme PON1 is associated with HDL and also contributes to the HDL-mediated antioxidative activity by reducing lipid peroxidation of LDL and HDL through a specific cysteine residue [79]. Other HDL-associated enzymes and apolipoprotein components, including LpPLA $\mathrm{L}_{2}$, LCAT, apoA-II, apoE, and apoJ also contribute to HDL's antioxidant properties [80-82]. Furthermore, HDL inhibits the formation of reactive oxygen species and reduces intracellular oxidative stress [83-85]. The attenuated cellular generation of ROS may be implicated in the antioxidative effect of HDL on endothelial cells $[42,86]$.

\subsection{Vasodilatory Activites}

One of the most important functions of HDL is its vasodilatory effect, which is mainly seen in the increase in the availability of nitric oxide (NO) in the endothelial cells $[87,88]$ and stimulating the generation and release of prostacyclin [89]. The initial step in the activation of NO production involves the binding of HDL to SR-BI, which initiates signaling in the endothelium [90]. The following intracellular events are facilitated by endothelial protein kinase $\mathrm{B}$ and intracellular $\mathrm{Ca}^{2+}$ mobilization, an increase in ceramide levels, and phosphorylation of endothelial NO synthase (eNOs) [42,87,91,92].

In addition, HDL, by its anti-oxidant activity, decreases the activity of nicotinamide adenine dinucleotide phosphate oxidase in the endothelium and decreases the formation of superoxide anions, which are potent inactivators of NO. Thereby, the bioavailability of $\mathrm{NO}$ is increased [93]. Vasodilatory actions of HDL also comprise the ABCG1 mediated efflux of cholesterol and 7-oxysterols, enhancing eNOs dimerization, leading to decreased production of reactive oxygen species [94].

\section{Fetal Lipoproteins Show Altered Concentrations and Unique Composition}

In cord blood, the concentration and composition of plasma lipoproteins are unique, suggesting that these particles may have an altered function in the developing fetus. While LDL represents the major class of lipoproteins in adult serum, HDL carries more than $50 \%$ of the cholesterol in fetal circulation. Although LDL and VLDL are detectable in the fetal circuit, but at low concentrations [95-99]. In the fetus, lipoproteins differ not only in concentrations but also in compositions, when compared with lipoproteins in adult plasma. In particular, the proteome of HDL has been shown to differ substantially from that in adults $[10,99]$. All studies investigating differences between maternal and fetal HDL found that only ApoE was present in higher concentrations compared to adult HDL, while all other apolipoproteins such as ApoA-I, ApoC-II, ApoC-III, and ApoD were lower (Figure 2) $[10,95,100,101]$. ApoA-I exerts a variety of important functions, such as interaction with cellular receptors, activation of LCAT, and anti-atherogenic activities [101-103]. ApoA-I further contributes to the anti-oxidative capacity of HDL, therefore lower levels in fetal HDL indicate diminished anti-oxidant function $[10,95,101]$. ApoE, which shows higher abundance on fetal HDL, plays an important role in cholesterol transport function by redistributing excess cholesterol from cells, to cells requiring it for metabolic processes such as membrane biosynthesis for cell proliferation or repair [104,105]. Large apoE enriched HDL particles are involved in the reverse cholesterol transport as ligands of SR-BI [9] and ABCG1 [105]. Further, apoE facilitates HDL binding to receptors of the LDL-receptor family [106]. In addition, apoE induces serum PON1 activity and stability comparable to apoA-I [107] and is reported as a major physiological activator of the lecithin-cholesterol acyltransferase (LCAT) [108]. Therefore, it appears that one function of HDL in the fetus is the transport of cholesterol to tissues as is accomplished by LDL in the adult $[10,95]$. Furthermore, studies on fetal HDL reported 5-fold lower PON1 mass and activity levels than in adults, which may be linked with a reduced anti-oxidative capacity and reduced defense against oxidative stress [10,109-111]. 
Although the proteomic differences between adult and cord blood HDL have been well described, there is currently no literature on the sphingolipid content of fetal HDL. The most abundant sphingolipid in HDL is sphingomyelin, which plays an important role in HDL functionality, by regulating fluidity and cholesterol efflux from different cells [112]. Furthermore, sphingomyelin affects the activity of enzymes involved in HDL metabolism and modulates the anti-oxidative properties of HDL $[53,113]$. Therefore, a highly interesting aspect for future studies would be to analyze the sphingolipidome of cord blood HDL, which could help to improve our understanding of the role and function of fetal HDL.

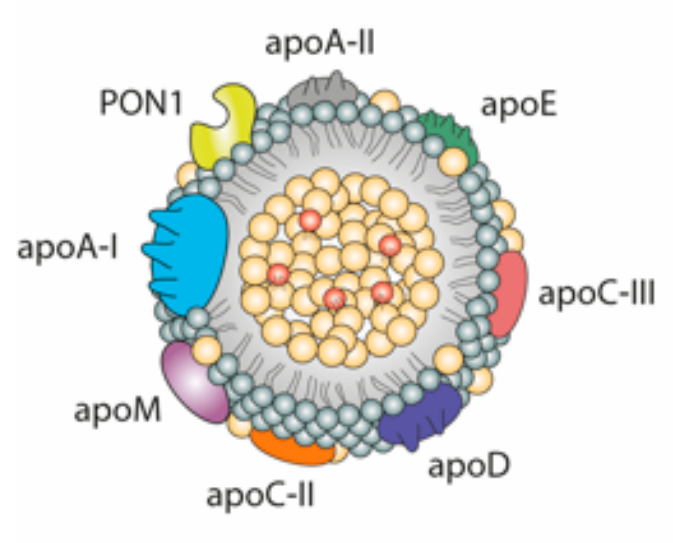

Adult HDL

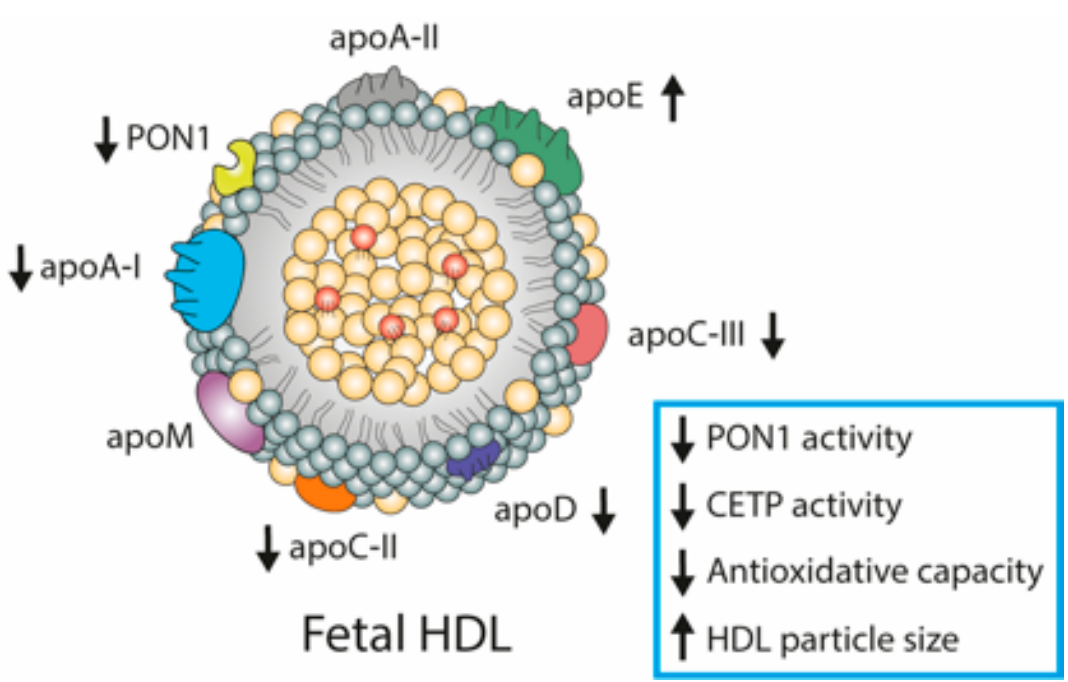

Figure 2. Schematic representation of differences between adult- and fetal HDL composition and function (indicated with black arrows). Cord blood-derived HDL exhibits several alterations in the apolipoprotein composition, such as decreased levels of apoA-I, apoC-III, apoD, and apoC-II and higher levels of apoE. In the fetus, the activity of CETP is decreased, while the mass and activity of PON1 and the antioxidative capacity are decreased. Fetal HDL is characterized by increased HDL particle size. HDL, high-density lipoprotein; apo, apolipoprotein; PON1, paraoxonase 1; CETP, cholesteryl-ester transfer protein.

\section{HDL Metabolism in Cord Blood}

Since there are strong differences in the fetal HDL composition, it is not surprising that HDL metabolism also significantly differs in fetal circulation. Sreckovic et al. showed that the activity of CETP was 55\% lower in cord-compared to maternal serum, whereas LCAT activity did not differ [10]. Interestingly, it has been shown that CETP inhibition enhances the capacity of SR-BI and ABCG1 dependent efflux to the large HDL2 particles [114]. The decreased CETP activity and enrichment of HDL particles with apoE suggest a highly altered metabolism of HDL particles in fetal circulation [10]. Furthermore, analyses of subclass distribution revealed a shift in HDL subclasses, with a higher content of very large HDL particles, further supporting the hypothesis of a different physiological role of fetal HDL than in adults [109].

Fetal HDL is unique in every way, whether in composition or metabolism. However, there is not much literature on how these differences affect the function of HDL in the fetus and what specific physiological roles it may trigger.

\section{The Role of Cord Blood-Derived HDL in Maintaining Fetoplacental Vascular Integrity}

\subsection{The Feto-Placental Endothelium}

Understanding the mechanisms that underlie placental cholesterol transfer lies, at least in part, in the fetoplacental endothelium. The fetoplacental vasculature is unique in its lack of innervation, singular in being independent of the autonomic regulation to which other vascular beds are subject [115]. Therefore, locally produced vasoactive mediators such 
as NO, endothelin-1, and angiotensin II regulate placental vascular resistance [115-117]. Moreover, the placental vasculature responds differently to humoral factors than vessels in other vascular beds. For example, the placental vasculature is the only vascular bed that has been reported to constrict rather than dilate in response to prostaglandin E2. It also demonstrates blunted responses to other vascular mediators including acetylcholine, bradykinin, and angiotensin II [118-120]. Interestingly it has been shown that inhibited and impaired angiogenesis further contribute to placental vascular resistance in fetal growthrestricted pregnancies, creating structural changes that restrict blood flow [118]. This study underpins the importance of an adequate perfusion of the placental tissue for peri- and postnatal health of the offspring.

The fetoplacental circulation allows the villous arteries to carry deoxygenated and nutrient-depleted fetal blood via the cord from the fetus to the placenta. After the exchange of oxygen and nutrients in the tissue, the villous veins carry fresh oxygenated and nutrientrich blood circulating back to the fetal systemic circulation [121].

Studies have shown that an imbalance in the production of these vasoactive agents in the placenta is associated with the incidence of pregnancy disorders [122,123].

\subsection{HDL-Sphingosine-1-Phosphate (S1P) as an Important Regulator of the Feto-Placental Vasculature}

$\mathrm{S} 1 \mathrm{P}$ is a bioactive lipid and is involved in the regulation of the vasomotor tone through induction of $\mathrm{NO}$ and prostacyclin synthesis $[87,124]$. In the circulation, this sphingolipid is mainly produced by erythrocytes, platelets, and vascular endothelial cells $[125,126]$. Once released from these cells into the bloodstream, S1P mainly binds to HDL via binding to apoM, while a small fraction is transported by albumin or other lipoproteins [49]. It has been shown that the half-life of HDL-associated S1P is 4-fold increased, when compared to S1P linked to albumin, indicating the importance of the carrier protein [127]. S1P is a ligand for five different $G$ protein-coupled receptors, named S1P receptors 1-5 (S1PR15) [128]. On endothelial cells, S1PR1-3 are expressed, with S1PR1 showing the highest abundance. Through interaction with S1PR1, S1P can activate several signal cascades, which play a key role in vascular homeostasis. Mice lacking the endothelial S1PR1 exhibit a pro-inflammatory phenotype, showing the significance of S1P-S1PR1 signal transduction on vascular protection [129]. Several studies suggest that S1P signaling is responsible for many of the cardio-protective properties of HDL, including the enhancement of endothelial barrier function and the induced vasodilator production $[87,124,130]$. Interestingly, during disorders such as cardiovascular disease or diabetes, the functionality of HDL-S1P has been shown to be reduced [131-133]. However, there are only a few available studies on the influence of HDL-S1P on the fetus and the fetoplacental unit.

In a study examining S1P in cord blood-derived HDL, S1P was shown to be present on fetal HDL and also bound to apoM, as is the case in the maternal circulation [134]. Further, S1PR1 was found as the predominant receptor expressed on the fetoplacental vasculature [134]. Ligation of S1P with its receptors elicits cell-type-specific cytoskeletal rearrangements $[49,135,136]$. Experiments on the effect of fetal HDL on cytoskeletal remodeling revealed that S1P-HDL isolated from cord blood triggers reorganization of actin filaments, resulting in an enhanced placental barrier function [134]. Using human umbilical vein endothelial cells, Wilkerson et al. also showed that HDL-associated S1P strengthens the endothelial barrier more persistently than albumin-bound S1P [137]. Moreover, Del Gaudio and colleagues observed that fetal HDL induces vasorelaxation of precontracted placental chorionic arteries [134]. The same authors further investigated the role of cord blood-derived HDL and S1P on the fetoplacental endothelium [138]. Primary fetal placental endothelial cells were approached by and challenged with TNF $\alpha$ to induce inflammation. They showed that incubation with fetal HDL-S1P complex from healthy donors diminished the ability of TNF $\alpha$ to activate signaling of NF- $\mathrm{KB}$ and expression of pro-inflammatory markers [138]. Angiotensin II is a stimulator of NADPH oxidase, which produces reactive oxygen species, leading to a vascular inflammatory response [139]. After treatment of primary fetal placental endothelial cells with angiotensin II, the production of reactive oxygen 
species was blunted in the presence of fetal HDL-S1P, whereas it was preserved when pre-incubated with an S1P receptor antagonist, suggesting that S1P signaling accounts for some of the vasculoprotective functions of HDL at the fetoplacental endothelium [138].

\subsection{Protective Functions of Lipoprotein Associated Phospholipase A2 ( $\left.L p P L A_{2}\right)$ on the Feto-Placental Endothelium}

The enzyme LpPLA $A_{2}$ is mainly produced by macrophages and binds to lipoproteins when secreted into circulation. In adults, $\mathrm{LpPLA}_{2}$ is mainly bound to LDL (80\%), while the remainder is bound to HDL [140]. The preferred substrate for hydrolysis of $\mathrm{LpPLA}_{2}$ represents the platelet-activating factor (PAF), which is an important mediator of inflammation [141]. Activity and mass of LpPLA 2 are altered in several pathologies such as hypercholesterolemia, diabetes, essential hypertension, and atherosclerosis and have therefore been the target of many clinical studies [142-145].

In a study focusing on $\mathrm{LPPLA}_{2}$ in the fetal circulation, HDL was identified as the major carrier, which is in contrast to adults [146]. In addition, this study reported that placental macrophages express LpPLA ${ }_{2}$, whose activity was increased by insulin, pro-inflammatory cytokines, and leptin [146]. Fetal HDL- LpPLA 2 was shown to have a beneficial effect on endothelial barrier function, which was abrogated with a specific LpPLA 2 inhibitor [146]. Interestingly, $\mathrm{LpPLA}_{2}$ levels in cord blood were inversely correlated with markers of oxidative stress [146]. These results suggest an important role of $\mathrm{LPPLA}_{2}$ on the placental endothelium and the fetus through athero-protective and anti-oxidative actions.

\section{Pregnancy-Related Diseases Affects HDL Metabolism and Function}

Severe changes in HDL metabolism as well as in parameters of HDL function have been reported in several inflammatory conditions including obesity [147-149], diabetes [150-152], cardiovascular disease [153,154], chronic kidney disease [155-157] or liver disease $[158,159]$. Impairment of HDL function may have pro-atherogenic properties and promote the inflammatory state. Changes in HDL functionalities have also been demonstrated in pregnancy-related diseases such as preeclampsia and gestational diabetes mellitus, which we will briefly summarize in the following chapter.

\subsection{Preeclampsia Associated Changes in HDL Composition and Function}

Preeclampsia (PE) is a hypertensive pregnancy-associated disorder, which develops usually after 20 weeks of gestation. This syndrome affects $2-8 \%$ of pregnancies worldwide and is a leading cause of maternal and fetal mortality $[160,161]$. This multiorgan disorder is defined as de novo hypertension (systolic blood pressure $\geq 140 \mathrm{~mm} \mathrm{Hg}$, diastolic blood pressure $\geq 90 \mathrm{~mm} \mathrm{Hg}$ ) and proteinuria ( $\geq 300 \mathrm{mg} / 24 \mathrm{~h}$ ) [162]. Risk factors for the development of PE are pre-pregnancy body mass index, age, ethnicity (black women are at higher risk), primiparity, multiple pregnancies, and history of certain diseases before pregnancy such as chronic hypertension, diabetes mellitus, or renal disease [163]. In countries with lowand middle-income, PE and its convulsive form eclampsia account for 10-15\% of direct maternal deaths $[164,165]$. This disorder is also associated with profound risks for the fetus including preterm birth, growth retardation, and death [166]. Mothers, affected by PE, but also their infants have a higher risk to develop cardiovascular disease later in life $[167,168]$. Nowadays, the only definitive treatment for PE is the management of clinical symptoms and delivery of the baby, which in turn increases the rate of preterm birth $[165,169]$. As the primary cause of $\mathrm{PE}$, it has been suggested that impaired placentation and the subsequent systemic activation of the endothelium results in clinical manifestations [164].

During a healthy pregnancy, the vascular function has been shown to improve with gestational age [170], whereas obesity, a risk factor for PE, reduces endothelium-dependent and -independent vasodilation in mothers [171]. Interestingly, a study reported flowinduced dilatation in isolated vessels from healthy pregnant women, but not in arteries isolated from women diagnosed with PE [172]. These results suggest that enhanced responses to shear stress in the maternal circulation during pregnancy are important and, when absent as in PE, may contribute to the increase in maternal blood pressure [172]. 
Dyslipidemia in mothers diagnosed with PE has been reported in several studies, characterized by higher levels of total cholesterol, non-HDL-C, and triglycerides, but lower levels of HDL-C during the third trimester [173]. Due to the cardioprotective properties of $\mathrm{HDL}$, changes in its function may contribute to the increased risk of cardiovascular events later in life in mothers, but also in children $[174,175]$.

Einbinder et al. observed a decrease in PON1 lactonase activity in mothers affected by PE, indicating a decreased anti-oxidative and anti-inflammatory activity of HDL [176] (Figure 3). Moreover, they observed lower expression of endothelial NO synthase and an increased expression of the adhesion molecule VCAM-1 after preincubating human umbilical vein endothelial cells with isolated HDL from PE mothers [176]. Other studies focusing on structures of HDL and LDL in PE reported marked oxidative modifications, such as malondialdehyde and lipohydroperoxides in lipids and proteins of the isolated particles $[177,178]$. These results indicate that the markedly altered lipoprotein profile is due to PE-driven oxidative stress in the maternal systemic circulation. Other studies confirmed the reduction of PON1 activity in mothers suffering from PE, possibly due to PE-associated increased oxidative stress [177,179-181].

Of particular interest, the PE-associated oxidative modifications of lipids in HDL and LDL were also found in fetal lipoproteins, showing that also the infants are affected by increased oxidative stress and clear transplacental transmission of these effects in PE [182]. Similar to the results in PE mothers [177], PON1 activity was also shown to be decreased in the cord blood of the newborns [182]. In another study, HDL isolated from cord blood of PE pregnancies was reported to be linked with significantly reduced levels of apoM [138]. Given that levels of S1P are usually highly correlated with apoM levels, these results suggest less endothelial protection by this bioactive lipid [138]. Additionally, HDL from PE mothers has been shown to be depleted in apoM as well as S1P, accompanied with less anti-oxidative capacity [183].

Interestingly, another study reported an increased total- and HDL-mediated cholesterol efflux capacity of maternal and fetal PE sera, whereas ABCA1-mediated cholesterol efflux was decreased. This was partially explained by the increased concentration of apoE in maternal and fetal circulation. The authors proposed that the increased cholesterol efflux might be a rescue mechanism to remove excess cholesterol from cells to reduce lipid peroxidation [184].

Studies reported increased levels of $\mathrm{LpPLA}_{2}$ in maternal PE plasma and the placenta $[185,186]$ as well as in the fetus [187], which may represent a compensatory mechanism to control PAF and inflammatory responses.

Alterations in HDL function and composition may contribute to the endothelial dysfunction observed in mothers affected by PE. Whether this impairment also contributes to the increased cardiovascular morbidity of these women and children later in life remains to be elucidated.

\subsection{HDL in Gestational Diabetes Mellitus (GDM)}

GDM is a condition in which women without a history of diabetes develop hyperglycemia during pregnancy. GDM is the most common disorder during pregnancy, affecting up to $22 \%$ of all pregnancies, with increasing prevalence worldwide [188,189]. Women diagnosed with GDM, have an increased risk of developing diabetes, hyperlipidemia, hypertension, and coronary heart disease later in life [190-192]. Therefore, lifelong health monitoring of these women is meanwhile recommended. Similar to PE, risk factors for GDM also include age, ethnicity, and obesity [193]. However, GDM not only affects the health of the mother but also fetal growth and the long-term health of the offspring. The most prominent adverse outcome of GDM complicated pregnancies represents macrosomia with complications including metabolic abnormalities, impaired immune system, degraded antioxidant status, and potential metabolic syndrome in adulthood [194].

In general, diabetes mellitus is associated with an altered lipid profile with increased levels of triglycerides, elevated LDL, and reduced levels of HDL [150]. Diabetic dyslipi- 
demia is not only characterized by changed levels, but also by different structures, function, and metabolism of lipoproteins. Studies reported decreased levels of HDL in type 2 diabetes mellitus (T2DM), with predominance of the small, protein-rich particles, which can undergo rapid catabolism $[150,195]$. The changes in HDL subclass distribution result from the increased transfer of triglycerides on HDL, mediated by CETP [196] and the increased activity of lipolytic enzymes such as hepatic lipase [197-199]. There is increasing evidence that low HDL levels may have a direct impact on plasma glucose and thereby contribute to the pathophysiology of T2DM [200]. Several experimental and clinical studies have suggested that HDL lowers blood glucose levels, by increased uptake of glucose from skeletal muscle via activation of the AMP-activated kinase pathway [200-202] and further through stimulation of pancreatic $\beta$-cell insulin secretion [201,203,204]. Other properties of HDL, such as its pivotal role in reverse cholesterol transport, as well as its anti-inflammatory capabilities in immune cells and metabolic tissues, may contribute to enhanced insulin sensitivity [200].

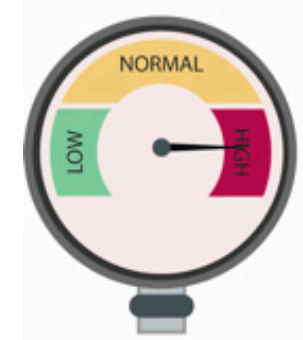

Preeclampsia

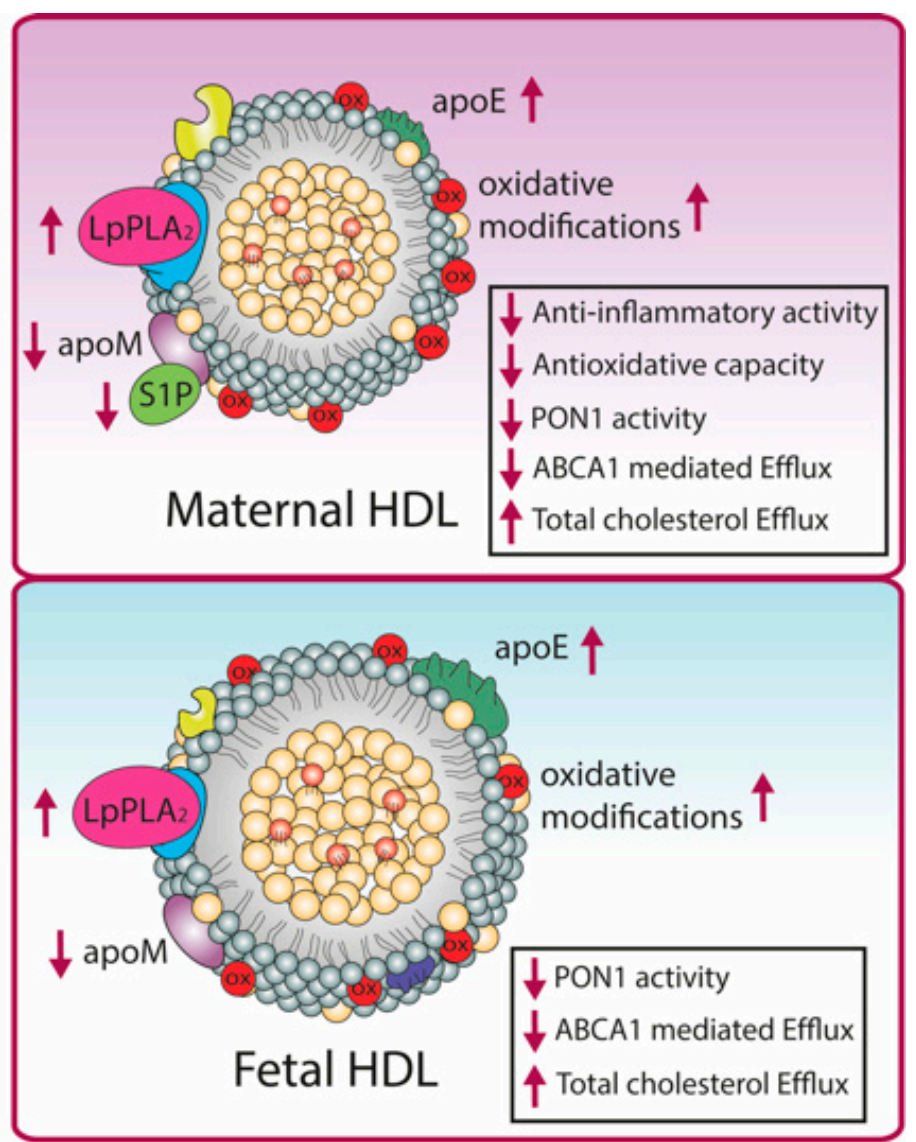

Figure 3. PE affects maternal and fetal HDL composition and function. Changes are indicated with purple arrows. In maternal HDL, a decrease in PON1 activity, apoM, and S1P content was observed, whereas apoE and LpPLA 2 were increased. These changes in HDL composition were associated with reduced anti-inflammatory and anti-oxidative activity, but increased cholesterol efflux capacity. Fetal HDL of PE pregnancies showed similar changes, with reduced PON1 activity and apoM, but increased $\mathrm{LpPLA}_{2}$ and apoE, accompanied by increased cholesterol efflux capacity. Oxidative modifications of lipids were detected in both maternal and fetal HDL. HDL, high-density lipoprotein; apo, apolipoprotein; PON1, paraoxonase 1; LpPLA 2, lipoprotein-associated phospholipase A2.

In women with GDM, levels of triglycerides are markedly increased during pregnancy, while levels of HDL-C are decreased in the second and third trimesters [173]. Recent research on HDL subclass distribution in GDM revealed that small HDL particles are associated with GDM and provide a potential screening tool for early identification $[205,206]$. 
Mokkala et al. showed that women developing GDM have a distinct lipid profile in early pregnancy, with small-sized HDL particles being the strongest predictors for GDM [206].

In a study by Sreckovic et al., GDM-associated changes of HDL function and composition were examined in maternal as well as fetal HDL [207]. Shotgun proteomics of isolated HDL revealed lower levels of apoM and increased levels of the acute-phase reactant SAA on both, maternal and fetal GDM HDL [207] (Figure 4). Since apoM represents the main carrier of the vasoprotective S1P, the reduction of apoM on GDM HDL might contribute to endothelial dysfunction observed in GDM [208]. This was supported by another group using a migration assay with human umbilical vein endothelial cells [209]. Maternal GDM HDL showed less closure of cell migration, which was induced by TNF $\alpha$, than control HDL [209]. Levels of apoA-I as well as mass and activity of PON1 were significantly decreased in maternal GDM HDL [207], similar to another study [209]. ApoA-I, as well as PON1, are important anti-oxidant components of HDL, therefore these results suggest decreased anti-oxidative protection $[78,210]$. On fetal GDM HDL, the abundance of PON1 was only barely detected, while activity was found to be reduced [207]. Interestingly, also HDL remodeling is altered during GDM. Both, maternal and fetal GDM HDL showed larger particle size than controls. Further, cholesterol efflux capacity was reduced in maternal as well as fetal GDM HDL [207]. Studies on LpPLA 2 in GDM revealed higher activity on maternal as well as fetal HDL, which might be relevant to exert protective activities against oxidative stress [146].

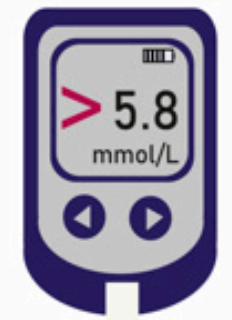

1

Gestational Diabetes

Mellitus

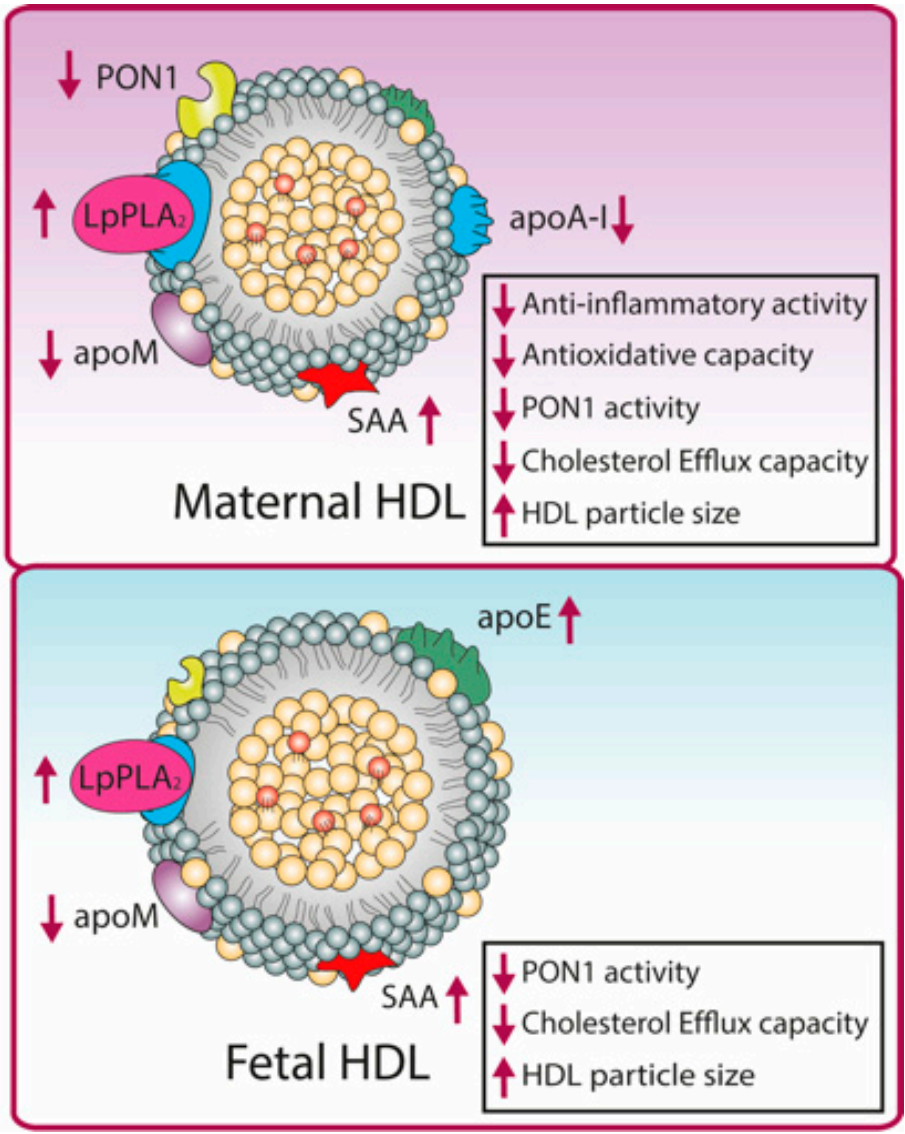

Figure 4. GDM affects maternal and fetal HDL composition and function. Changes are indicated with purple arrows. In maternal HDL, a decrease in PON1 activity and mass, apoM, and apoA-I content were observed, whereas SAA and LpPLA 2 were increased. These changes in HDL composition were associated with reduced anti-inflammatory and anti-oxidative activity and reduced cholesterol efflux capacity. Fetal GDM-HDL showed the same alterations in PON1 and LpPLA 2 activity, apoM and SAA content, and further increased apoE content. GDM was also accompanied by the increased particle size of both maternal and fetal HDL. HDL, high-density lipoprotein; apo, apolipoprotein; PON1, paraoxonase 1; LpPLA2, lipoprotein-associated phospholipase A2; SAA, serum amyloid A. 
Concluding, HDL proteome and size are markedly altered in GDM in both, maternal and fetal circulation. However, how these alterations affect the protective properties of fetal HDL and whether these alterations persist and are involved in the higher risk of becoming vascular diseases in offspring of GDM pregnancies later in life requires further studies.

\section{Conclusions}

Endogenous, as well as maternally-provided cholesterol, are important for fetal development. Although lipoprotein metabolism is separated between mother and fetus, maternal hyper- and hypocholesterolemia affect infant health and growth. Transplacental cholesterol transport from maternal lipoproteins to the fetal side involves receptor-mediated uptake of cholesterol from the syncytium and transport through the stroma. Cholesterol is then secreted/effluxed from the fetal endothelium to acceptors such as lipid-poor apolipoproteins and HDL.

With its unique apolipoprotein composition with high levels of apoE, fetal HDL seems to have an important cholesterol transport function that is accomplished by LDL in adults. Due to its distinct composition, it may also have an important role in atheroprotection. However, research should focus on elucidating the physiological function of fetal HDL and how this is developing with aging of the newborns.

Maintaining the vascular integrity of the fetoplacental vasculature is important for an adequate supply of oxygen and nutrients to the fetus and therefore crucial for fetal well-being. It has been shown that HDL-associated S1P is an important regulator of placental vascular inflammation, but also improves endothelial barrier function and induces vasorelaxation, thus playing an important role in maintaining vascular integrity. Further, $\mathrm{LpPLA}_{2}$ has been suggested to act anti-inflammatory and to improve vascular barrier function in the placental endothelium.

HDL composition and function have been shown to be altered in pregnancy disorders such as PE and GDM. Of importance, these changes were also observed in the fetus of complicated pregnancies, therefore suggesting placental transmission of these effects. Disease-induced alterations of HDL composition and function might contribute to the pathophysiology of PE and GDM. Long-term follow-up studies are needed to clarify whether alterations in HDL composition and function (i) persist into adulthood and (ii) whether these changes are related to the increased risk of vascular pathologies later in life.

This review summarizes the current literature on the composition and function of fetal HDL in health and disease. Extensive future research is needed to further understand the physiological role of HDL in the fetus.

Author Contributions: Conceptualization, J.T.S. and G.M.; writing-review and editing, J.T.S., C.W., G.M.; visualization, J.T.S.; supervision, G.M.; All authors have read and agreed to the published version of the manuscript.

Funding: This work was supported by the Austrian Science Fund (FWF) (DOC 31-B26) and the Medical University of Graz through the PhD Program Inflammatory Disorders in Pregnancy (DP-iDP).

Acknowledgments: Open Access Funding by the Austrian Science Fund (FWF).

Conflicts of Interest: The authors declare no conflict of interest.

\section{Abbreviations}

$\begin{array}{ll}\text { ABCA1 } & \text { ATP-binding cassette A1 } \\ \text { ABCG1 } & \text { ATP-binding cassette G1 } \\ \text { apo } & \text { Apolipoprotein } \\ \text { CETP } & \text { Cholesteryl-ester transfer protein } \\ \text { eNOs } & \text { Endothelial nitric oxide synthase } \\ \text { HDL } & \text { High-density lipoprotein } \\ \text { HDL-C } & \text { High-density lipoprotein cholesterol }\end{array}$




$\begin{array}{ll}\text { GDM } & \text { Gestational diabetes mellitus } \\ \text { NO } & \text { Nitric oxide } \\ \text { LCAT } & \text { Lecithin-cholesteryl acyltransferase } \\ \text { LDL } & \text { Low-density lipoprotein } \\ \text { LDL-R } & \text { Low-density lipoprotein receptor } \\ \text { LpPLA2 } & \text { Lipoprotein associated phospholipase A2 } \\ \text { LR-P1 } & \text { LDL receptor related protein 1 } \\ \text { LPL } & \text { Lipoprotein lipase } \\ \text { PAF } & \text { Platelet activating factor } \\ \text { PON1 } & \text { Paraoxonase 1 } \\ \text { SAA } & \text { Serum amyloid A } \\ \text { SR-BI } & \text { Scavenger receptor BI } \\ \text { S1P } & \text { Sphingosine-1-phosphate } \\ \text { VLDL } & \text { Very low-density lipoprotein }\end{array}$

\section{References}

1. Roux, C.; Wolf, C.; Mulliez, N.; Gaoua, W.; Cormier, V.; Chevy, F.; Citadelle, D. Role of cholesterol in embryonic development. Am. J. Clin. Nutr. 2000, 71, 1270S-1279S. [CrossRef]

2. Huang, X.; Litingtung, Y.; Chiang, C. Region-specific requirement for cholesterol modification of sonic hedgehog in patterning the telencephalon and spinal cord. Development 2007, 134, 2095-2105. [CrossRef]

3. Woollett, L.A. Maternal cholesterol in fetal development: Transport of cholesterol from the maternal to the fetal circulation. Am. J. Clin. Nutr. 2005, 82, 1155-1161. [CrossRef]

4. Woollett, L.A. Review: Transport of maternal cholesterol to the fetal circulation. Placenta 2011, 32, S218-S221. [CrossRef] [PubMed]

5. Jayalekshmi, V.S.; Ramachandran, S. Maternal cholesterol levels during gestation: Boon or bane for the offspring? Mol. Cell. Biochem. 2021, 476, 401-416. [CrossRef] [PubMed]

6. Wyne, K.L.; Woollett, L.A. Transport of maternal LDL and HDL to the fetal membranes and placenta of the Golden Syrian hamster is mediated by receptor-dependent and receptor-independent processes. J. Lipid Res. 1998, 39, 518-530. [CrossRef]

7. Schmid, K.E.; Davidson, W.S.; Myatt, L.; Woollett, L.A. Transport of cholesterol across a BeWo cell monolayer. J. Lipid Res. 2003, 44, 1909-1918. [CrossRef] [PubMed]

8. Wittmaack, F.M.; Gafvels, M.E.; Brönner, M.; Matsuo, H.; McCrae, K.R.; Tomaszewski, J.E.; Robinson, S.L.; Strickland, D.K.; Strauss, J.F. Localization and regulation of the human very low density lipoprotein/apolipoprotein-E receptor: Trophoblast expression predicts a role for the receptor in placental lipid transport. Endocrinology 1995, 136, 340-348. [CrossRef] [PubMed]

9. Stefulj, J.; Panzenboeck, U.; Becker, T.; Hirschmugl, B.; Schweinzer, C.; Lang, I.; Marsche, G.; Sadjak, A.; Lang, U.; Desoye, G.; et al. Human Endothelial Cells of the Placental Barrier Efficiently Deliver Cholesterol to the Fetal Circulation via ABCA1 and ABCG1. Circ. Res. 2009, 104, 600-608. [CrossRef]

10. Sreckovic, I.; Birner-Gruenberger, R.; Obrist, B.; Stojakovic, T.; Scharnagl, H.; Holzer, M.; Scholler, M.; Philipose, S.; Marsche, G.; Lang, U.; et al. Distinct composition of human fetal HDL attenuates its anti-oxidative capacity. Biochim. Biophys. Acta (BBA) Mol. Cell Biol. Lipids 2013, 1831, 737-746. [CrossRef]

11. Murphy, S.P.; Abrams, B.F. Changes in energy intakes during pregnancy and lactation in a national sample of US women. Am. J. Public Heal. 1993, 83, 1161-1163. [CrossRef] [PubMed]

12. Villar, J.; Cogswell, M.; Kestler, E.; Castillo, P.; Menendez, R.; Repke, J.T. Effect of fat and fat-free mass deposition during pregnancy on birth weight. Am. J. Obstet. Gynecol. 1992, 167, 1344-1352. [CrossRef]

13. Zeng, Z.; Liu, F.; Li, S. Metabolic Adaptations in Pregnancy: A Review. Ann. Nutr. Metab. 2017, 70, 59-65. [CrossRef]

14. Wiznitzer, A.; Mayer, A.; Novack, V.; Sheiner, E.; Gilutz, H.; Malhotra, A.; Novack, L. Association of lipid levels during gestation with preeclampsia and gestational diabetes mellitus: A population-based study. Am. J. Obstet. Gynecol. 2009, 201, 482.e1-482.e8. [CrossRef]

15. Herrera, E. Lipid Metabolism during Pregnancy and its Implications for Fetal Growth. Curr. Pharm. Biotechnol. 2014, 15, 24-31. [CrossRef]

16. Herrera, E.; Lasunción, M.A.; Gomez-Coronado, D.; Aranda, P.; López-Luna, P.; Maier, I. Role of lipoprotein lipase activity on lipoprotein metabolism and the fate of circulating triglycerides in pregnancy. Am. J. Obstet. Gynecol. 1988, 158, 1575-1583. [CrossRef]

17. Alvarez, J.J.; Montelongo, A.; Iglesias, A.; Lasunción, M.A.; Herrera, E. Longitudinal Study on Lipoprotein Profile, High Density Lipoprotein Subclass, and Postheparin Lipases during Gestation in Women. J. Lipid Res. 1996, 37, 299-308. [CrossRef]

18. Stanley, K.; Fraser, R.; Bruce, C. Physiological changes in insulin resistance in human pregnancy: Longitudinal study with the hyperinsulinaemic euglycaemic clamp technique. Br. J. Obstet. Gynaecol. 1998, 105, 756-759. [CrossRef]

19. Ryan, E.A.; Enns, L. Role of Gestational Hormones in the Induction of Insulin Resistance. J. Clin. Endocrinol. Metab. 1988, 67, 341-347. [CrossRef] [PubMed]

20. Knopp, R.H.; Warth, M.R.; Charles, D.; Childs, M.; Li, J.R.; Mabuchi, H.; Van Allen, M.I. Lipoprotein Metabolism in Pregnancy, Fat Transport to the Fetus, and the Effects of Diabetes. Neonatology 1986, 50, 297-317. [CrossRef] [PubMed] 
21. Elliott, J.A. The Effect of Pregnancy on the Control of Lipolysis in Fat Cells Isolated from Human Adipose Tissue. Eur. J. Clin. Investig. 1975, 5, 159-163. [CrossRef]

22. Ramos, P.; Herrera, E. Reversion of insulin resistance in the rat during late pregnancy by 72-h glucose infusion. Am. J. Physiol. Metab. 1995, 269, E858-E863. [CrossRef]

23. Weinstein, I.; Soler-Argilaga, C.; Werner, H.V.; Heimberg, M. Effects of ethynyloestradiol on the metabolism of [1-14C]-oleate by perfused livers and hepatocytes from female rats. Biochem. J. 1979, 180, 265-271. [CrossRef]

24. Iglesias, A.; Montelongo, A.; Herrera, E.; Lasunción, M.A. Changes in cholesteryl ester transfer protein activity during normal gestation and postpartum. Clin. Biochem. 1994, 27, 63-68. [CrossRef]

25. Kinnunen, P.K.J.; Unnérus, H.A.; Ranta, T.; Ehnholm, C.; Nikkilä, J.E.A.; Seppälä, M. Activities of post-heparin plasma lipoprotein lipase and hepatic lipase during pregnancy and lactation. Eur. J. Clin. Investig. 1980, 10, 469-474. [CrossRef]

26. Palinski, W.; Nicolaides, E.; Liguori, A.; Napoli, C. Influence of Maternal Dysmetabolic Conditions during Pregnancy on Cardiovascular Disease. J. Cardiovasc. Transl. Res. 2009, 2, 277-285. [CrossRef] [PubMed]

27. Schroepfer, G.J. Oxysterols: Modulators of Cholesterol Metabolism and Other Processes. Physiol. Rev. 2000, 80, 361-554. [CrossRef]

28. Dietschy, J.M.; Turley, S.D.; Spady, D.K. Role of liver in the maintenance of cholesterol and low density lipoprotein homeostasis in different animal species, including humans. J. Lipid Res. 1993, 34, 1637-1659. [CrossRef]

29. Wadsack, C.; Hammer, A.; Levak-Frank, S.; Desoye, G.; Kozarsky, K.; Hirschmugl, B.; Sattler, W.; Malle, E. Selective Cholesteryl Ester Uptake from High Density Lipoprotein by Human First Trimester and Term Villous Trophoblast Cells. Placenta 2003, 24, 131-143. [CrossRef]

30. Weaver, D.D.; Solomon, B.D.; Akin-Samson, K.; Kelley, R.I.; Muenke, M. Cyclopia (synophthalmia) in Smith-Lemli-Opitz syndrome: First reported case and consideration of mechanism. Am. J. Med Genet. Part C: Semin. Med Genet. 2010, 154C, 142-145. [CrossRef]

31. Lunghi, L.; Ferretti, M.E.; Medici, S.; Biondi, C.; Vesce, F. Control of human trophoblast function. Reprod. Biol. Endocrinol. 2007, 5, 6. [CrossRef]

32. Lager, S.; Powell, T.L. Regulation of Nutrient Transport across the Placenta. J. Pregnancy 2012, 2012, 179827. [CrossRef] [PubMed]

33. Desoye, G.; Gauster, M.; Wadsack, C. Placental transport in pregnancy pathologies. Am. J. Clin. Nutr. 2011, 94, 1896S-1902S. [CrossRef]

34. Kallol, S.; Albrecht, C. Materno-fetal cholesterol transport during pregnancy. Biochem. Soc. Trans. 2020, 48, 775-786. [CrossRef] [PubMed]

35. Burke, K.T.; Colvin, P.L.; Myatt, L.; Graf, G.A.; Schroeder, F.; Woollett, L.A. Transport of maternal cholesterol to the fetus is affected by maternal plasma cholesterol concentrations in the Golden Syrian hamster. J. Lipid Res. 2009, 50, 1146-1155. [CrossRef] [PubMed]

36. Yeşilkaya, E.; Karaer, K.; Bideci, A.; Çamurdan, O.; Perçin, E.F.; Cinaz, P. Dubowitz Syndrome: A Cholesterol Metabolism Disorder? Genet. Couns. Med Psychol. Ethical Asp. 2008, 19, 287-290.

37. Maymunah, A.-O.; Kehinde, O.; Abidoye, G.; Oluwatosin, A. Hypercholesterolaemia in pregnancy as a predictor of adverse pregnancy outcome. Afr. Heal. Sci. 2015, 14, 967-973. [CrossRef] [PubMed]

38. Catov, J.M.; Newman, A.B.; Roberts, J.M.; Kelsey, S.F.; Sutton-Tyrrell, K.; Harris, T.B.; Colbert, L.; Rubin, S.M.; Satterfield, S.; Ness, R.B. Preterm Delivery and Later Maternal Cardiovascular Disease Risk. Epidemiology 2007, 18, 733-739. [CrossRef]

39. Khoury, J.; Henriksen, T.; Christophersen, B.; Tonstad, S. Effect of a cholesterol-lowering diet on maternal, cord, and neonatal lipids, and pregnancy outcome: A randomized clinical trial. Am. J. Obstet. Gynecol. 2005, 193, 1292-1301. [CrossRef]

40. Jan, M.R.; Nazli, R.; Shah, J.; Akhtar, T. A Study of Lipoproteins in Normal and Pregnancy Induced Hypertensive Women in Tertiary Care Hospitals of the North West Frontier Province-Pakistan. Hypertens. Pregnancy 2010, 31, 292-299. [CrossRef]

41. Vrijkotte, T.G.M.; Krukziener, N.; Hutten, B.A.; Vollebregt, K.C.; Van Eijsden, M.; Twickler, M.B. Maternal Lipid Profile During Early Pregnancy and Pregnancy Complications and Outcomes: The ABCD Study. J. Clin. Endocrinol. Metab. 2012, 97, 3917-3925. [CrossRef]

42. Kontush, A. HDL-mediated mechanisms of protection in cardiovascular disease. Cardiovasc. Res. 2014, 103, 341-349. [CrossRef]

43. Feig, J.E.; Hewing, B.; Smith, J.D.; Hazen, S.L.; Fisher, E.A. High-Density Lipoprotein and Atherosclerosis Regression. Circ. Res. 2014, 114, 205-213. [CrossRef] [PubMed]

44. Pappa, E.; Elisaf, M.S.; Kostara, C.; Bairaktari, E.; Tsimihodimos, V.K. Cardioprotective Properties of HDL: Structural and Functional Considerations. Curr. Med. Chem. 2020, 27, 2964-2978. [CrossRef] [PubMed]

45. Tailleux, A.; Fruchart, J.C.; Parkes, J.G. HDL Heterogeneity and Atherosclerosis. Crit. Rev. Clin. Lab. Sci. 1996, 33, 163-201. [CrossRef]

46. Kostner, G.; Alaupovic, P. Composition and structure of plasma lipoproteins. Separation and quantification of the lipoprotein families occurring in the high density lipoproteins of human plasma. Biochemistry 1972, 11, 3419-3428. [CrossRef] [PubMed]

47. Duriez, P.; Fruchart, J.C. High-density lipoprotein subclasses and apolipoprotein A-I. Clin. Chim. Acta 1999, 286, 97-114. [CrossRef]

48. Ahnström, J.; Faber, K.; Axler, O.; Dahlbäck, B. Hydrophobic ligand binding properties of the human lipocalin apolipoprotein M. J. Lipid Res. 2007, 48, 1754-1762. [CrossRef] [PubMed] 
49. Christoffersen, C.; Obinata, H.; Kumaraswamy, S.B.; Galvani, S.; Ahnström, J.; Sevvana, M.; Egerer-Sieber, C.; Muller, Y.A.; Hla, T.; Nielsen, L.B.; et al. Endothelium-protective sphingosine-1-phosphate provided by HDL-associated apolipoprotein M. Proc. Natl. Acad. Sci. USA 2011, 108, 9613-9618. [CrossRef]

50. Kontush, A.; Lindahl, M.; Lhomme, M.; Calabresi, L.; Chapman, M.J.; Davidson, W.S. Structure of HDL: Particle Subclasses and Molecular Components. Handb. Exp. Pharmacol. 2014, 224, 3-51. [CrossRef]

51. Garelnabi, M.; Litvinov, D.; Mahini, H. Antioxidant and anti-inflammatory role of paraoxonase 1: Implication in arteriosclerosis diseases. N. Am. J. Med Sci. 2012, 4, 523-532. [CrossRef]

52. Draganov, D.I.; Teiber, J.F.; Speelman, A.; Osawa, Y.; Sunahara, R.; La Du, B.N. Human paraoxonases (PON1, PON2, and PON3) are lactonases with overlapping and distinct substrate specificities. J. Lipid Res. 2005, 46, 1239-1247. [CrossRef]

53. Kontush, A.; Lhomme, M.; Chapman, M.J. Unraveling the complexities of the HDL lipidome. J. Lipid Res. 2013, 54, $2950-2963$. [CrossRef] [PubMed]

54. Baker, P.W.; Rye, K.-A.; Gamble, J.R.; Vadas, M.A.; Barter, P.J. Ability of reconstituted high density lipoproteins to inhibit cytokine-induced expression of vascular cell adhesion molecule-1 in human umbilical vein endothelial cells. J. Lipid Res. 1999, 40, 345-353. [CrossRef]

55. Trieb, M.; Wolf, P.; Knuplez, E.; Weger, W.; Schuster, C.; Peinhaupt, M.; Holzer, M.; Trakaki, A.; Eichmann, T.; Lass, A.; et al. Abnormal composition and function of high-density lipoproteins in atopic dermatitis patients. Allergy 2018, 74, 398-402. [CrossRef]

56. Trakaki, A.; Marsche, G. High-Density Lipoprotein (HDL) in Allergy and Skin Diseases: Focus on Immunomodulating Functions. Biomedicines 2020, 8, 558. [CrossRef]

57. Trakaki, A.; Sturm, G.J.; Pregartner, G.; Scharnagl, H.; Eichmann, T.O.; Trieb, M.; Knuplez, E.; Holzer, M.; Stadler, J.T.; Heinemann, A.; et al. Allergic rhinitis is associated with complex alterations in high-density lipoprotein composition and function. Biochim. Biophys. Acta (BBA) Mol. Cell Biol. Lipids 2019, 1864, 1280-1292. [CrossRef]

58. Curcic, S.; Holzer, M.; Frei, R.; Pasterk, L.; Schicho, R.; Heinemann, A.; Marsche, G. Neutrophil effector responses are suppressed by secretory phospholipase A2 modified HDL. Biochim. Biophys. Acta (BBA) Mol. Cell Biol. Lipids 2015, 1851, 184-193. [CrossRef]

59. Yetukuri, L.; Söderlund, S.; Koivuniemi, A.; Seppänen-Laakso, T.; Niemelä, P.S.; Hyvönen, M.; Taskinen, M.-R.; Vattulainen, I.; Jauhiainen, M.; Orešič, M. Composition and lipid spatial distribution of HDL particles in subjects with low and high HDL-cholesterol. J. Lipid Res. 2010, 51, 2341-2351. [CrossRef]

60. Wiesner, P.; Leidl, K.; Boettcher, A.; Schmitz, G.; Liebisch, G. Lipid profiling of FPLC-separated lipoprotein fractions by electrospray ionization tandem mass spectrometry. J. Lipid Res. 2009, 50, 574-585. [CrossRef]

61. Serna, J.; García-Seisdedos, D.; Alcázar, A.; Lasunción, M. Ángel; Busto, R.; Pastor, Óscar Quantitative lipidomic analysis of plasma and plasma lipoproteins using MALDI-TOF mass spectrometry. Chem. Phys. Lipids 2015, 189, 7-18. [CrossRef]

62. Von Eckardstein, A.; Nofer, J.-R.; Assmann, G. High Density Lipoproteins and Arteriosclerosis. Arter. Thromb. Vasc. Biol. 2001, 21, 13-27. [CrossRef] [PubMed]

63. Khera, A.V.; Cuchel, M.; De La Llera-Moya, M.; Rodrigues, A.; Burke, M.F.; Jafri, K.; French, B.C.; Phillips, J.A.; Mucksavage, M.L.; Wilensky, R.L.; et al. Cholesterol Efflux Capacity, High-Density Lipoprotein Function, and Atherosclerosis. N. Engl. J. Med. 2011, 364, 127-135. [CrossRef]

64. Li, X.-M.; Tang, W.H.W.; Mosior, M.K.; Huang, Y.; Wu, Y.; Matter, W.; Gao, V.; Schmitt, D.; DiDonato, J.A.; Fisher, E.A.; et al. Paradoxical Association of Enhanced Cholesterol Efflux With Increased Incident Cardiovascular Risks. Arter. Thromb. Vasc. Biol. 2013, 33, 1696-1705. [CrossRef] [PubMed]

65. Attie, A.D.; Kastelein, J.P.; Hayden, M.R. Pivotal role of ABCA1 in reverse cholesterol transport influencing HDL levels and susceptibility to atherosclerosis. J. Lipid Res. 2001, 42, 1717-1726. [CrossRef]

66. Wang, N.; Lan, D.; Chen, W.; Matsuura, F.; Tall, A.R. ATP-binding cassette transporters G1 and G4 mediate cellular cholesterol efflux to high-density lipoproteins. Proc. Natl. Acad. Sci. USA 2004, 101, 9774-9779. [CrossRef]

67. Tang, C.; Oram, J.F. The cell cholesterol exporter ABCA1 as a protector from cardiovascular disease and diabetes. Biochim. Biophys. Acta (BBA) Mol. Cell Biol. Lipids 2009, 1791, 563-572. [CrossRef]

68. Mc, P.; Wj, J.; Gh, R. Mechanisms and Consequences of Cellular Cholesterol Exchange and Transfer. Available online: https: / / pubmed.ncbi.nlm.nih.gov/3297153/ (accessed on 14 October 2020).

69. Kennedy, M.A.; Barrera, G.C.; Nakamura, K.; Baldán, Á.; Tarr, P.; Fishbein, M.C.; Frank, J.; Francone, O.L.; Edwards, P.A. ABCG1 has a critical role in mediating cholesterol efflux to HDL and preventing cellular lipid accumulation. Cell Metab. 2005, 1, 121-131. [CrossRef]

70. Rothblat, G.H.; Phillips, M.C. High-density lipoprotein heterogeneity and function in reverse cholesterol transport. Curr. Opin. Lipidol. 2010, 21, 229-238. [CrossRef]

71. Ouimet, M.; Barrett, T.J.; Fisher, E.A. HDL and Reverse Cholesterol Transport. Circ. Res. 2019, 124, 1505-1518. [CrossRef]

72. Navab, M.; Imes, S.S.; Hama, S.Y.; Hough, G.P.; Ross, L.A.; Bork, R.W.; Valente, A.J.; Berliner, J.A.; Drinkwater, D.C.; Laks, H.; et al. Monocyte transmigration induced by modification of low density lipoprotein in cocultures of human aortic wall cells is due to induction of monocyte chemotactic protein 1 synthesis and is abolished by high density lipoprotein. J. Clin. Investig. 1991, 88, 2039-2046. [CrossRef]

73. Cockerill, G.W.; Rye, K.-A.; Gamble, J.R.; Vadas, M.A.; Barter, P.J. High-Density Lipoproteins Inhibit Cytokine-Induced Expression of Endothelial Cell Adhesion Molecules. Arter. Thromb. Vasc. Biol. 1995, 15, 1987-1994. [CrossRef] [PubMed] 
74. Calabresia, L.; Franceschinia, G.; Sirtori, C.R.; De Palma, A.; Saresellac, M.; Ferrantec, P.; Taramellib, D. Inhibition of VCAM-1 Expression in Endothelial Cells by Reconstituted High Density Lipoproteins. Biochem. Biophys. Res. Commun. 1997, $238,61-65$. [CrossRef]

75. Nofer, J.-R.; Geigenmüller, S.; Göpfert, C.; Assmann, G.; Buddecke, E.; Schmidt, A. High density lipoprotein-associated lysosphingolipids reduce E-selectin expression in human endothelial cells. Biochem. Biophys. Res. Commun. 2003, 310, 98-103. [CrossRef] [PubMed]

76. Bursill, C.A.; Castro, M.L.; Beattie, D.T.; Nakhla, S.; Van Der Vorst, E.; Heather, A.K.; Barter, P.J.; Rye, K.-A. High-Density Lipoproteins Suppress Chemokines and Chemokine Receptors In Vitro and In Vivo. Arter. Thromb. Vasc. Biol. 2010, 30, 1773-1778. [CrossRef] [PubMed]

77. Panzenböck, U.; Stocker, R. Formation of methionine sulfoxide-containing specific forms of oxidized high-density lipoproteins. Biochim. Biophys. Acta (BBA) Proteins Proteom. 2005, 1703, 171-181. [CrossRef] [PubMed]

78. Garner, B.; Waldeck, A.R.; Witting, P.K.; Rye, K.-A.; Stocker, R. Oxidation of High Density Lipoproteins. J. Biol. Chem. 1998, 273, 6088-6095. [CrossRef]

79. Aviram, M.; Billecke, S.; Sorenson, R.; Bisgaier, C.; Newton, R.; Rosenblat, M.; Erogul, J.; Hsu, C.; Dunlop, C.; La Du, B. Paraoxonase Active Site Required for Protection Against LDL Oxidation Involves Its Free Sulfhydryl Group and Is Different From That Required for Its Arylesterase/Paraoxonase Activities. Arter. Thromb. Vasc. Biol. 1998, 18, 1617-1624. [CrossRef]

80. Miyata, M.; Smith, J.D. Apolipoprotein E allele-specific antioxidant activity and effects on cytotoxicity by oxidative insults and $\beta$-amyloid peptides. Nat. Genet. 1996, 14, 55-61. [CrossRef]

81. Kontush, A.; Chapman, M.J. Functionally Defective High-Density Lipoprotein: A New Therapeutic Target at the Crossroads of Dyslipidemia, Inflammation, and Atherosclerosis. Pharmacol. Rev. 2006, 58, 342-374. [CrossRef]

82. Kontush, A.; Chapman, M.J. Antiatherogenic small, dense HDL-guardian angel of the arterial wall? Nat. Clin. Pr. Neurol. 2006, 3, 144-153. [CrossRef]

83. Yvan-Charvet, L.; Pagler, T.A.; Seimon, T.A.; Thorp, E.; Welch, C.L.; Witztum, J.L.; Tabas, I.; Tall, A.R. ABCA1 and ABCG1 Protect Against Oxidative Stress-Induced Macrophage Apoptosis During Efferocytosis. Circ. Res. 2010, 106, 1861-1869. [CrossRef] [PubMed]

84. Tabet, F.; Lambert, G.; Torres, L.F.C.; Hou, L.; Sotirchos, I.; Touyz, R.M.; Jenkins, A.J.; Barter, P.J.; Rye, K.-A. Lipid-Free Apolipoprotein A-I and Discoidal Reconstituted High-Density Lipoproteins Differentially Inhibit Glucose-Induced Oxidative Stress in Human Macrophages. Arter. Thromb. Vasc. Biol. 2011, 31, 1192-1200. [CrossRef] [PubMed]

85. Robbesyn, F.; Garcia, V.; Auge, N.; Vieira, O.; Frisach, M.; Salvayre, R.; Negre-Salvayre, A. HDL counterbalance the proinflammatory effect of oxidized LDL by inhibiting intracellular reactive oxygen species rise, proteasome activation, and subsequent NF- $\mathrm{KB}$ activation in smooth muscle cells. FASEB J. 2003, 17, 743-745. [CrossRef]

86. De Souza, J.A.; Vindis, C.; Nègre-Salvayre, A.; Rye, K.-A.; Couturier, M.; Thérond, P.; Chantepie, S.; Salvayre, R.; Chapman, M.J.; Kontush, A. Small, dense HDL 3 particles attenuate apoptosis in endothelial cells: Pivotal role of apolipoprotein A-I. J. Cell. Mol. Med. 2009, 14, 608-620. [CrossRef]

87. Nofer, J.-R.; Van Der Giet, M.; Tölle, M.; Wolinska, I.; Lipinski, K.V.W.; Baba, H.A.; Tietge, U.J.; Gödecke, A.; Ishii, I.; Kleuser, B.; et al. HDL induces NO-dependent vasorelaxation via the lysophospholipid receptor S1P3. J. Clin. Investig. 2004, 113, 569-581. [CrossRef]

88. Mineo, C.; Deguchi, H.; Griffin, J.H.; Shaul, P.W. Endothelial and antithrombotic actions of HDL. Circ. Res. 2006, 98, 1352-1364. [CrossRef]

89. Norata, G.D.; Callegari, E.; Inoue, H.; Catapano, A.L. HDL 3 Induces Cyclooxygenase-2 Expression and Prostacyclin Release in Human Endothelial Cells Via a p38 MAPK/CRE-Dependent Pathway: Effects on COX-2/PGI-Synthase Coupling. Arter. Thromb. Vasc. Biol. 2004, 24, 871-877. [CrossRef] [PubMed]

90. Movva, R.; Rader, D.J. Laboratory Assessment of HDL Heterogeneity and Function. Clin. Chem. 2008, 54, 788-800. [CrossRef]

91. Yuhanna, I.S.; Zhu, Y.; Cox, B.E.; Hahner, L.D.; Osborne-Lawrence, S.; Lu, P.; Marcel, Y.L.; Anderson, R.G.; Mendelsohn, M.E.; Hobbs, H.H.; et al. High-density lipoprotein binding to scavenger receptor-BI activates endothelial nitric oxide synthase. Nat. Med. 2001, 7, 853-857. [CrossRef]

92. Drew, B.G.; Fidge, N.H.; Gallon-Beaumier, G.; Kemp, B.E.; Kingwell, B.A. High-density lipoprotein and apolipoprotein AI increase endothelial NO synthase activity by protein association and multisite phosphorylation. Proc. Natl. Acad. Sci. USA 2004, 101, 6999-7004. [CrossRef]

93. Van Linthout, S.; Spillmann, F.; Lorenz, M.; Meloni, M.; Jacobs, F.; Egorova, M.; Stangl, V.; De Geest, B.; Schultheiss, H.-P.; TschöpeC. Vascular-Protective Effects of High-Density Lipoprotein Include the Downregulation of the Angiotensin II Type 1 Receptor. Hypertens. 2009, 53, 682-687. [CrossRef] [PubMed]

94. Chen, W.; Xiao, H.; Rizzo, A.N.; Zhang, W.; Mai, Y.; Ye, M. Endothelial Nitric Oxide Synthase Dimerization Is Regulated by Heat Shock Protein 90 Rather than by Phosphorylation. PLoS ONE 2014, 9, e0105479. [CrossRef] [PubMed]

95. Averna, M.; Barbagallo, C.M.; Di Paola, G.; Labisi, M.; Pinna, G.; Marino, G.; Dimita, U.; Notarbartolo, A. Lipids, Lipoproteins and Apolipoproteins AI AII, B, CII, CIII and E in Newborns. Neonatology 1991, 60, 187-192. [CrossRef] [PubMed]

96. Saha, N.; Wong, H. Serum HDL Cholesterol and Apolipoprotein AI, All and B Levels in Singapore Newborns. Neonatology 1987, 52, 93-96. [CrossRef] [PubMed] 
97. Bastida, S.; Sánchez-Muniz, F.J.; Cuesta, C.; Perea, S.; Aragonés, A. Male and female cord blood lipoprotein profile differences throughout the term-period. J. Périnat. Med. 1997, 25, 184-191. [CrossRef] [PubMed]

98. Merzouk, H.; Meghelli-Bouchenak, M.; El-Korso, N.; Belleville, J.; Prost, J. Low birth weight at term impairs cord serum lipoprotein compositions and concentrations. Eur. J. Nucl. Med. Mol. Imaging 1998, 157, 321-326. [CrossRef] [PubMed]

99. Nagasaka, H.; Chiba, H.; Kikuta, H.; Akita, H.; Takahashi, Y.; Yanai, H.; Hui, S.-P.; Fuda, H.; Fujiwara, H.; Kobayashi, K. Unique character and metabolism of high density lipoprotein (HDL) in fetus. Atherosclerosis 2002, 161, 215-223. [CrossRef]

100. Dolphin, P.J.; Breckenridge, W.C.; Dolphin, M.A.; Tan, M.H. The lipoproteins of human umbilical cord blood apolipoprotein and lipid levels. Atherosclerosis 1984, 51, 109-122. [CrossRef]

101. Wang, N.; Silver, D.L.; Costet, P.; Tall, A.R. Specific Binding of ApoA-I, Enhanced Cholesterol Efflux, and Altered Plasma Membrane Morphology in Cells Expressing ABC1. J. Biol. Chem. 2000, 275, 33053-33058. [CrossRef]

102. Moore, R.E.; Navab, M.; Millar, J.S.; Zimetti, F.; Hama, S.; Rothblat, G.H.; Rader, D.J. Increased Atherosclerosis in Mice Lacking Apolipoprotein A-I Attributable to Both Impaired Reverse Cholesterol Transport and Increased Inflammation. Circ. Res. 2005, 97, 763-771. [CrossRef]

103. Sorci-Thomas, M.G.; Bhat, S.; Thomas, M.J. Activation of lecithin:cholesterol acyltransferase by HDL ApoA-I central helices. Clin. Lipidol. 2009, 4, 113-124. [CrossRef] [PubMed]

104. Koo, C.; Innerarity, T.L.; Mahley, R.W. Obligatory role of cholesterol and apolipoprotein E in the formation of large cholesterolenriched and receptor-active high density lipoproteins. J. Biol. Chem. 1985, 260, 11934-11943. [CrossRef]

105. Mahley, R.W. Apolipoprotein E: Cholesterol transport protein with expanding role in cell biology. Science 1988, 240, 622-630. [CrossRef]

106. Rosales, C.; Tang, D.; Gillard, B.K.; Courtney, H.S.; Pownall, H.J. Apolipoprotein E Mediates Enhanced Plasma High-Density Lipoprotein Cholesterol Clearance by Low-Dose Streptococcal Serum Opacity Factor via Hepatic Low-Density Lipoprotein Receptors In Vivo. Arter. Thromb. Vasc. Biol. 2011, 31, 1834-1841. [CrossRef]

107. Gaidukov, L.; Viji, R.I.; Yacobson, S.; Rosenblat, M.; Aviram, M.; Tawfik, D.S. ApoE Induces Serum Paraoxonase PON1 Activity and Stability Similar to ApoA-I. Biochemistry 2010, 49, 532-538. [CrossRef]

108. Zhao, Y.; Thorngate, F.E.; Weisgraber, K.H.; Williams, D.L.; Parks, J.S. Apolipoprotein E Is the Major Physiological Activator of Lecithin-Cholesterol Acyltransferase (LCAT) on Apolipoprotein B Lipoproteins. Biochemistry 2005, 44, 1013-1025. [CrossRef] [PubMed]

109. Gugliucci, A.; Numaguchi, M.; Caccavello, R.; Kimura, S. Paraoxonase 1 lactonase activity and distribution in the HDL subclasses in the cord blood. Redox Rep. 2014, 19, 124-132. [CrossRef]

110. Chen, J.; Kumar, M.; Chan, W.; Berkowitz, G.; Wetmur, J.G. Increased influence of genetic variation on PON1 activity in neonates. Environ. Heal. Perspect. 2003, 111, 1403-1409. [CrossRef]

111. Altunhan, H.; Annagür, A.; Kurban, S.; Ertuğrul, S.; Konak, M.; Örs, R. Total oxidant, antioxidant, and paraoxonase levels in babies born to pre-eclamptic mothers. J. Obstet. Gynaecol. Res. 2013, 39, 898-904. [CrossRef] [PubMed]

112. Martínez-Beamonte, R.; Lou-Bonafonte, J.M.; Martínez-Gracia, M.V.; Osada, J. Sphingomyelin in High-Density Lipoproteins: Structural Role and Biological Function. Int. J. Mol. Sci. 2013, 14, 7716-7741. [CrossRef]

113. Zerrad-Saadi, A.; Therond, P.; Chantepie, S.; Couturier, M.; Rye, K.-A.; Chapman, M.J.; Kontush, A. HDL3-Mediated Inactivation of LDL-Associated Phospholipid Hydroperoxides Is Determined by the Redox Status of Apolipoprotein A-I and HDL Particle Surface Lipid Rigidity. Arter. Thromb. Vasc. Biol. 2009, 29, 2169-2175. [CrossRef] [PubMed]

114. Bellanger, N.; Julia, Z.; Villard, E.F.; El Khoury, P.; Duchene, E.; Chapman, M.J.; Fournier, N.; Le Goff, W.; Guérin, M. Functionality of postprandial larger HDL2 particles is enhanced following CETP inhibition therapy. Atherosclerosis 2012, 221, 160-168. [CrossRef] [PubMed]

115. Myatt, L. Control of vascular resistance in the human placenta. Placenta 1992, 13, 329-341. [CrossRef]

116. Odum, C.U.; Pipkin, F.B. Studies on the response of isolated human chorionic plate artery strips to angiotensin II in normal pregnancy and in pregnancy induced hypertension. West Afr. J. Med. 1989, 8, 251-256. [PubMed]

117. Paradis, A.; Zhang, L. Role of endothelin in uteroplacental circulation and fetal vascular function. Curr. Vasc. Pharmacol. 2013, 11, 594-605. [CrossRef] [PubMed]

118. Su, E.J. Role of the fetoplacental endothelium in fetal growth restriction with abnormal umbilical artery Doppler velocimetry. Am. J. Obstet. Gynecol. 2015, 213, S123-S130. [CrossRef] [PubMed]

119. Boura, A.; Walters, W. Autacoids and the control of vascular tone in the human umbilical-placental circulation. Placenta 1991, 12, 453-477. [CrossRef]

120. Mak, K.K.-W.; Gude, N.M.; Walters, W.A.W.; Boura, A.L.A. Effects of vasoactive autacoids on the human umbilical-fetal placental vasculature. BJOG: Int. J. Obstet. Gynaecol. 1984, 91, 99-106. [CrossRef]

121. Wadsack, C.; Desoye, G.; Hiden, U. The feto-placental endothelium in pregnancy pathologies. Wien. Med. Wochenschr. 2012, 162, 220-224. [CrossRef]

122. Stuart, M.; Clark, D.A.; Sunderji, S.G.; Allen, J.B.; Yambo, T.; Elrad, H.; Slott, J.H. Decreased prostacyclin production: A Characteristic of chronic placental insufficiency syndromes. Lancet 1981, 317, 1126-1128. [CrossRef]

123. Giles, W. Placental Nitric Oxide Synthase Activity and Abnormal Umbilical Artery Flow Velocity Waveforms. Obstet. Gynecol. 1997, 89, 49-52. [CrossRef] 
124. Sattler, K.; Levkau, B. Sphingosine-1-phosphate as a mediator of high-density lipoprotein effects in cardiovascular protection. Cardiovasc. Res. 2008, 82, 201-211. [CrossRef] [PubMed]

125. Venkataraman, K.; Lee, Y.-M.; Michaud, J.; Thangada, S.; Ai, Y.; Bonkovsky, H.L.; Parikh, N.S.; Habrukowich, C.; Hla, T. Vascular Endothelium As a Contributor of Plasma Sphingosine 1-Phosphate. Circ. Res. 2008, 102, 669-676. [CrossRef]

126. Gazit, S.L.; Mariko, B.; Thérond, P.; Decouture, B.; Xiong, Y.; Couty, L.; Bonnin, P.; Baudrie, V.; Le Gall, S.M.; Dizier, B.; et al Platelet and Erythrocyte Sources of S1P Are Redundant for Vascular Development and Homeostasis, but Both Rendered Essential After Plasma S1P Depletion in Anaphylactic Shock. Circ. Res. 2016, 119, e110-e126. [CrossRef] [PubMed]

127. Kimura, T.; Sato, K.; Kuwabara, A.; Tomura, H.; Ishiwara, M.; Kobayashi, I.; Ui, M.; Okajima, F. Sphingosine 1-Phosphate May Be a Major Component of Plasma Lipoproteins Responsible for the Cytoprotective Actions in Human Umbilical Vein Endothelial Cells. J. Biol. Chem. 2001, 276, 31780-31785. [CrossRef]

128. Lee, M.-J.; Van Brocklyn, J.R.; Thangada, S.; Liu, C.H.; Hand, A.R.; Menzeleev, R.; Spiegel, S.; Hla, T. Sphingosine-1-Phosphate as a Ligand for the G Protein-Coupled Receptor EDG-1. Science 1998, 279, 1552-1555. [CrossRef] [PubMed]

129. Galvani, S.; Sanson, M.; Blaho, V.A.; Swendeman, S.L.; Obinata, H.; Conger, H.; Dahlbäck, B.; Kono, M.; Proia, R.L.; Smith, J.D.; et al. HDL-bound sphingosine 1-phosphate acts as a biased agonist for the endothelial cell receptor S1P1to limit vascular inflammation. Sci. Signal. 2015, 8, ra79. [CrossRef]

130. Argraves, K.M.; Argraves, W.S. HDL serves as a S1P signaling platform mediating a multitude of cardiovascular effects. J. Lipid Res. 2007, 48, 2325-2333. [CrossRef]

131. Brinck, J.W.; Thomas, A.; Lauer, E.; Jornayvaz, F.R.; Brulhart-Meynet, M.-C.; Prost, J.-C.; Pataky, Z.; Löfgren, P.; Hoffstedt, J.; Eriksson, M.; et al. Diabetes Mellitus Is Associated With Reduced High-Density Lipoprotein Sphingosine-1-Phosphate Content and Impaired High-Density Lipoprotein Cardiac Cell Protection. Arter. Thromb. Vasc. Biol. 2016, 36, 817-824. [CrossRef]

132. Jing, X.-D.; Wei, X.-M.; Deng, S.-B.; Du, J.-L.; Liu, Y.-J.; She, Q. The relationship between the high-density lipoprotein (HDL)associated sphingosine-1-phosphate (S1P) and coronary in-stent restenosis. Clin. Chim. Acta 2015, 446, 248-252. [CrossRef]

133. Tong, X.; Peng, H.; Liu, D.; Ji, L.; Niu, C.; Ren, J.; Pan, B.; Hu, J.; Zheng, L.; Huang, Y. High-density lipoprotein of patients with Type 2 Diabetes Mellitus upregulates cyclooxgenase-2 expression and prostacyclin I-2 release in endothelial cells: Relationship with HDL-associated sphingosine-1-phosphate. Cardiovasc. Diabetol. 2013, 12, 27. [CrossRef] [PubMed]

134. Del Gaudio, I.; Sreckovic, I.; Zardoya-Laguardia, P.; Bernhart, E.; Christoffersen, C.; Frank, S.; Marsche, G.; Illanes, S.E.; Wadsack, C. Circulating cord blood HDL-S1P complex preserves the integrity of the feto-placental vasculature. Biochim. Biophys. Acta (BBA) Mol. Cell Biol. Lipids 2020, 1865, 158632. [CrossRef] [PubMed]

135. Donati, C.; Bruni, P. Sphingosine 1-phosphate regulates cytoskeleton dynamics: Implications in its biological response. Biochim. Biophys. Acta (BBA) Biomembr. 2006, 1758, 2037-2048. [CrossRef]

136. Mehta, D.; Konstantoulaki, M.; Ahmmed, G.U.; Malik, A.B. Sphingosine 1-Phosphate-induced Mobilization of Intracellular Ca2+ Mediates Rac Activation and Adherens Junction Assembly in Endothelial Cells. J. Biol. Chem. 2005, 280, 17320-17328. [CrossRef]

137. Wilkerson, B.A.; Grass, G.D.; Wing, S.B.; Argraves, W.S.; Argraves, K.M. Sphingosine 1-Phosphate (S1P) Carrier-dependent Regulation of Endothelial Barrier. J. Biol. Chem. 2012, 287, 44645-44653. [CrossRef]

138. Del Gaudio, I.; Hendrix, S.; Christoffersen, C.; Wadsack, C. Neonatal HDL Counteracts Placental Vascular Inflammation via S1P-S1PR1 Axis. Int. J. Mol. Sci. 2020, 21, 789. [CrossRef]

139. Brasier, A.R.; Recinos, A., III; Eledrisi, M.S. Vascular Inflammation and the Renin-Angiotensin System. Arter. Thromb. Vasc. Biol. 2002, 22, 1257-1266. [CrossRef]

140. McCall, M.R.; La Belle, M.; Forte, T.M.; Krauss, R.M.; Takanami, Y.; Tribble, D.L. Dissociable and nondissociable forms of platelet-activating factor acetylhydrolase in human plasma LDL: Implications for LDL oxidative susceptibility. Biochim. Biophys. Acta (BBA) Mol. Cell Biol. Lipids 1999, 1437, 23-36. [CrossRef]

141. Yost, C.C.; Weyrich, A.S.; Zimmerman, G.A. The platelet activating factor (PAF) signaling cascade in systemic inflammatory responses. Biochim. 2010, 92, 692-697. [CrossRef]

142. Satoh, F.; Imaizumi, T.-A.; Kawamura, Y.; Yoshida, H.; Takamatsu, S.; Takamatsu, M. Increased activity of the platelet-activating factor acetylhydrolase in plasma low density lipoprotein from patients with essential hypertension. Prostaglandins 1989, 37, 673-682. [CrossRef]

143. Tsimihodimos, V.; Karabina, S.-A.P.; Tambaki, A.P.; Bairaktari, E.; Miltiadous, G.; Goudevenos, J.A.; Cariolou, M.A.; Chapman, M.J.; Tselepis, A.D.; Elisaf, M. Altered distribution of platelet-activating factor-acetylhydrolase activity between LDL and HDL as a function of the severity of hypercholesterolemia. J. Lipid Res. 2002, 43, 256-263. [CrossRef]

144. Kolodgie, F.D.; Burke, A.P.; Skorija, K.S.; Ladich, E.; Kutys, R.; Makuria, A.T.; Virmani, R. Lipoprotein-Associated Phospholipase A 2 Protein Expression in the Natural Progression of Human Coronary Atherosclerosis. Arter. Thromb. Vasc. Biol. 2006, 26, 2523-2529. [CrossRef]

145. Serban, M.; Tanaseanu, C.; Kosaka, T.; Vidulescu, C.; Stoian, I.; Marta, D.S.; Tanaseanu, S.; Moldoveanu, E. Significance of platelet-activating factor acetylhydrolase in patients with non-insulin-dependent (type 2) diabetes mellitus. J. Cell. Mol. Med. 2002, 6, 643-647. [CrossRef]

146. Schliefsteiner, C.; Hirschmugl, B.; Kopp, S.; Curcic, S.; Bernhart, E.M.; Marsche, G.; Lang, U.; Desoye, G.; Wadsack, C. Maternal Gestational Diabetes Mellitus increases placental and foetal lipoprotein-associated Phospholipase A2 which might exert protective functions against oxidative stress. Sci. Rep. 2017, 7, 12628. [CrossRef] 
147. Stadler, J.T.; Marsche, G. Obesity-Related Changes in High-Density Lipoprotein Metabolism and Function. Int. J. Mol. Sci. 2020, 21, 8985. [CrossRef]

148. Rashid, S.; Genest, J. Effect of Obesity on High-density Lipoprotein Metabolism. Obesity 2007, 15, 2875-2888. [CrossRef]

149. Stadler, J.; Lackner, S.; Mörkl, S.; Trakaki, A.; Scharnagl, H.; Borenich, A.; Wonisch, W.; Mangge, H.; Zelzer, S.; Meier-Allard, N.; et al. Obesity Affects HDL Metabolism, Composition and Subclass Distribution. Biomedicines 2021, 9, 242. [CrossRef]

150. Farbstein, D.; Levy, A.P. HDL dysfunction in diabetes: Causes and possible treatments. Expert Rev. Cardiovasc. Ther. 2012, 10, 353-361. [CrossRef] [PubMed]

151. Srivastava, R.A.K. Dysfunctional HDL in diabetes mellitus and its role in the pathogenesis of cardiovascular disease. Mol. Cell. Biochem. 2017, 440, 167-187. [CrossRef]

152. Ganjali, S.; Dallinga-Thie, G.M.; Simental-Mendía, L.E.; Banach, M.; Pirro, M.; Sahebkar, A. HDL functionality in type 1 diabetes. Atherosclerosis 2017, 267, 99-109. [CrossRef] [PubMed]

153. Kosmas, C.E.; Martinez, I.; Sourlas, A.; Bouza, K.V.; Campos, F.N.; Torres, V.; Montan, P.D.; Guzman, E. High-density lipoprotein (HDL) functionality and its relevance to atherosclerotic cardiovascular disease. Drugs Context 2018, 7, 1-9. [CrossRef]

154. Rader, D.J.; Hovingh, G.K. HDL and cardiovascular disease. Lancet 2014, 384, 618-625. [CrossRef]

155. Holzer, M.; Schilcher, G.; Curcic, S.; Trieb, M.; Ljubojevic, S.; Stojakovic, T.; Scharnagl, H.; Kopecky, C.M.; Rosenkranz, A.R.; Heinemann, A.; et al. Dialysis Modalities and HDL Composition and Function. J. Am. Soc. Nephrol. 2015, 26, 2267-2276. [CrossRef]

156. Holzer, M.; Birner-Gruenberger, R.; Stojakovic, T.; El-Gamal, D.; Binder, V.; Wadsack, C.; Heinemann, A.; Marsche, G. Uremia Alters HDL Composition and Function. J. Am. Soc. Nephrol. 2011, 22, 1631-1641. [CrossRef] [PubMed]

157. Marsche, G.; Heine, G.H.; Stadler, J.T.; Holzer, M. Current Understanding of the Relationship of HDL Composition, Structure and Function to Their Cardioprotective Properties in Chronic Kidney Disease. Biomolecules 2020, 10, 1348. [CrossRef] [PubMed]

158. Trieb, M.; Horvath, A.; Birner-Gruenberger, R.; Spindelboeck, W.; Stadlbauer, V.; Taschler, U.; Curcic, S.; Stauber, R.E.; Holzer, M.; Pasterk, L.; et al. Liver disease alters high-density lipoprotein composition, metabolism and function. Biochim. Biophys. Acta (BBA) Mol. Cell Biol. Lipids 2016, 1861, 630-638. [CrossRef] [PubMed]

159. Fadaei, R.; Poustchi, H.; Meshkani, R.; Moradi, N.; Golmohammadi, T.; Merat, S. Impaired HDL cholesterol efflux capacity in patients with non-alcoholic fatty liver disease is associated with subclinical atherosclerosis. Sci. Rep. 2018, 8, 11691. [CrossRef] [PubMed]

160. Young, B.C.; Levine, R.J.; Karumanchi, S.A. Pathogenesis of Preeclampsia. Annu. Rev. Pathol. Mech. Dis. 2010, 5, 173-192. [CrossRef] [PubMed]

161. Gathiram, P.; Moodley, J. Pre-eclampsia: Its pathogenesis and pathophysiolgy. Cardiovasc. J. Afr. 2016, 27, 71-78. [CrossRef] [PubMed]

162. ACOG Committee on Obstetric Practice. Practice bulletin \#33: Diagnosis and management of preeclampsia and eclampsia. Obstet. Gynecol. 2002, 99, 159-167. [CrossRef]

163. Trogstad, L.; Magnus, P.; Stoltenberg, C. Pre-eclampsia: Risk factors and causal models. Best Pr. Res. Clin. Obstet. Gynaecol. 2011, 25, 329-342. [CrossRef] [PubMed]

164. Brown, C.M.; Garovic, V.D. Mechanisms and Management of Hypertension in Pregnant Women. Curr. Hypertens. Rep. 2011, 13, 338-346. [CrossRef]

165. Duley, L. The Global Impact of Pre-eclampsia and Eclampsia. Semin. Perinatol. 2009, 33, 130-137. [CrossRef]

166. Rugolo, L.M.S.D.S.; Bentlin, M.R.; Trindade, C.E.P. Preeclampsia: Effect on the Fetus and Newborn. NeoReviews 2011, 12, e198-e206. [CrossRef]

167. Benschop, L.; Duvekot, J.J.; Lennep, J.E.R.V. Future risk of cardiovascular disease risk factors and events in women after a hypertensive disorder of pregnancy. Heart 2019, 105, 1273-1278. [CrossRef]

168. Herrera-Garcia, G.; Contag, S. Maternal Preeclampsia and Risk for Cardiovascular Disease in Offspring. Curr. Hypertens. Rep. 2014, 16, 1-10. [CrossRef]

169. Goldenberg, R.L.; Culhane, J.F.; Iams, J.D.; Romero, R. Epidemiology and causes of preterm birth. Lancet 2008, 371, 75-84. [CrossRef]

170. Saarelainen, H.; Laitinen, T.; Raitakari, O.T.; Juonala, M.; Heiskanen, N.; Lyyra-Laitinen, T.; Viikari, J.S.; Vanninen, E.; Heinonen, S. Pregnancy-Related Hyperlipidemia and Endothelial Function in Healthy Women. Circ. J. 2006, 70, 768-772. [CrossRef] [PubMed]

171. Stewart, F.M.; Freeman, D.J.; Ramsay, J.E.; Greer, I.A.; Caslake, M.; Ferrell, W.R. Longitudinal Assessment of Maternal Endothelial Function and Markers of Inflammation and Placental Function throughout Pregnancy in Lean and Obese Mothers. J. Clin. Endocrinol. Metab. 2007, 92, 969-975. [CrossRef]

172. Cockell, A.P.; Poston, L. Flow-mediated vasodilatation is enhanced in normal pregnancy but reduced in preeclampsia. Hypertension 1997, 30, 247-251. [CrossRef]

173. Spracklen, C.N.; Smith, C.J.; Saftlas, A.F.; Robinson, J.G.; Ryckman, K.K. Maternal Hyperlipidemia and the Risk of Preeclampsia: A Meta-Analysis. Am. J. Epidemiology 2014, 180, 346-358. [CrossRef]

174. Brown, M.C.; Best, K.E.; Pearce, M.S.; Waugh, J.; Robson, S.C.; Bell, R. Cardiovascular disease risk in women with pre-eclampsia: Systematic review and meta-analysis. Eur. J. Epidemiol. 2013, 28, 1-19. [CrossRef] [PubMed]

175. Scantlebury, D.C.; Hayes, S.N. How Does Preeclampsia Predispose to Future Cardiovascular Disease? Curr. Hypertens. Rep. 2014, 16, 1-7. [CrossRef] 
176. Einbinder, Y.; Biron-Shental, T.; Agassi-Zaitler, M.; Tzadikevitch-Geffen, K.; Vaya, J.; Khatib, S.; Ohana, M.; Benchetrit, S.; Zitman-Gal, T. High-density lipoproteins (HDL) composition and function in preeclampsia. Arch. Gynecol. Obstet. 2018, 298, 405-413. [CrossRef]

177. León-Reyes, G.; Maida-Claros, R.F.; Urrutia-Medina, A.X.; Jorge-Galarza, E.; Guzmán-Grenfell, A.M.; Fuentes-García, S.; MedinaNavarro, R.; Moreno-Eutimio, M.A.; Muñoz-Sánchez, J.L.; Hicks, J.J.; et al. Oxidative profiles of LDL and HDL isolated from women with preeclampsia. Lipids Heal. Dis. 2017, 16, 1-9. [CrossRef] [PubMed]

178. Patil, S.B.; Kodliwadmath, M.V. Lipid peroxidation and antioxidant activity in complicated pregnancies. Clin. Exp. Obstet. Gynecol. 2009, 36, 110-112. [PubMed]

179. Kumru, S.; Aydin, S.; Gursu, M.; Ozcan, Z. Changes of serum paraoxonase (an HDL-cholesterol-associated lipophilic antioxidant) and arylesterase activities in severe preeclamptic women. Eur. J. Obstet. Gynecol. Reprod. Biol. 2004, 114, 177-181. [CrossRef] [PubMed]

180. Demir, B.; Demir, S.; Atamer, Y.; Guven, S.; Atamer, A.; Kocyigit, Y.; Hekimoglu, A.; Toprak, G. Serum Levels of Lipids, Lipoproteins and Paraoxonase Activity in Pre-Eclampsia. J. Int. Med Res. 2011, 39, 1427-1431. [CrossRef]

181. Uzun, H.; Benian, A.; Madazlı, R.; Topçuoğlu, M.; Aydın, S.; Albayrak, M. Circulating Oxidized Low-Density Lipoprotein and Paraoxonase Activity in Preeclampsia. Gynecol. Obstet. Investig. 2005, 60, 195-200. [CrossRef]

182. León-Reyes, G.; Sosa, S.E.Y.; Medina-Navarro, R.; Guzmán-Grenfell, A.M.; Medina-Urrutia, A.X.; Fuentes-García, S.; Hicks, G.J.J.; Torres-Ramos, Y.D. Oxidative modifications of foetal LDL-c and HDL-c lipoproteins in preeclampsia. Lipids Heal. Dis. 2018, 17, 110. [CrossRef]

183. Picot, M.; Croyal, M.; Duparc, T.; Combes, G.; Vayssière, C.; Perret, B.; Hamdi, S.; Martinez, L.; Genoux, A. Preeclampsia is associated with changes in the composition and dysfunction of high-density lipoproteins. Arch. Cardiovasc. Dis. Suppl. 2019, 11, e354. [CrossRef]

184. Mistry, H.D.; Kurlak, L.O.; Mansour, Y.T.; Zurkinden, L.; Mohaupt, M.G.; Escher, G. Increased maternal and fetal cholesterol efflux capacity and placental CYP27A1 expression in preeclampsia. J. Lipid Res. 2017, 58, 1186-1195. [CrossRef] [PubMed]

185. Gu, Y.; Burlison, S.; Wang, Y. PAF Levels and PAF-AH Activities in Placentas from Normal and Preeclamptic Pregnancies. Placenta 2006, 27, 744-749. [CrossRef] [PubMed]

186. Maki, N.; Magness, R.R.; Miyaura, S.; Gant, N.F.; Johnston, J.M. Platelet-activating factor-acetylhydrolase activity in normotensive and hypertensive pregnancies. Am. J. Obstet. Gynecol. 1993, 168, 50-54. [CrossRef]

187. Fan, P.; Liu, X.-H.; He, G.-L.; Zhang, S.; Zhang, J.-X.; Bai, H. Maternal and fetal plasma platelet-activating factor acetylhydrolase activity and distribution in pre-eclampsia. Pediatr. Res. 2012, 72, 426-431. [CrossRef]

188. Jenum, A.K.; Mørkrid, K.; Sletner, L.; Vangen, S.; Vange, S.; Torper, J.L.; Nakstad, B.; Voldner, N.; Rognerud-Jensen, O.H.; Berntsen, S.; et al. Impact of Ethnicity on Gestational Diabetes Identified with the WHO and the Modified International Association of Diabetes and Pregnancy Study Groups Criteria: A Population-Based Cohort Study. Eur J Endocrinol 2012, 166, 317-324. [CrossRef]

189. Ferrara, A. Increasing Prevalence of Gestational Diabetes Mellitus: A public health perspective. Diabetes Care 2007, 30, S141-S146. [CrossRef]

190. Bellamy, L.; Casas, J.-P.; Hingorani, A.D.; Williams, D. Type 2 diabetes mellitus after gestational diabetes: A systematic review and meta-analysis. Lancet 2009, 373, 1773-1779. [CrossRef]

191. Vrachnis, N.; Augoulea, A.; Iliodromiti, Z.; Lambrinoudaki, I.; Sifakis, S.; Creatsas, G. Previous Gestational Diabetes Mellitus and Markers of Cardiovascular Risk. Int. J. Endocrinol. 2012, 2012, 1-6. [CrossRef]

192. Davis, C.L.; Gutt, M.; Llabre, M.M.; Marks, J.B.; O'Sullivan, M.J.; Potter, J.E.; Landel, J.L.; Kumar, M.; Schneiderman, N.; Gellman, M.; et al. History of Gestational Diabetes, Insulin Resistance and Coronary Risk. J. Diabetes Complicat. 1999, 13, 216-223. [CrossRef]

193. Jovanovic, L. Gestational Diabetes Mellitus. JAMA 2001, 286, 2516-2518. [CrossRef]

194. Yessoufou, A.; Moutairou, K. Maternal Diabetes in Pregnancy: Early and Long-Term Outcomes on the Offspring and the Concept of "Metabolic Memory". Exp. Diabetes Res. 2011, 2011, 218598. [CrossRef] [PubMed]

195. Adiels, M.; Olofsson, S.-O.; Taskinen, M.-R.; Borén, J. Diabetic dyslipidaemia. Curr. Opin. Lipidol. 2006, 17, 238-246. [CrossRef] [PubMed]

196. Dallinga-Thie, G.M.; Dullaart, R.P.; Van Tol, A. Concerted actions of cholesteryl ester transfer protein and phospholipid transfer protein in type 2 diabetes: Effects of apolipoproteins. Curr. Opin. Lipidol. 2007, 18, 251-257. [CrossRef]

197. Van Deursen, D.; Jansen, H.; Verhoeven, A.J.M. Glucose increases hepatic lipase expression in HepG2 liver cells through upregulation of upstream stimulatory factors 1 and 2. Diabetologia 2008, 51, 2078-2087. [CrossRef] [PubMed]

198. Baynes, C.; Henderson, A.; Anyaoku, V.; Richmond, W.; Hughes, C.L.; Johnston, D.G.; Elkeles, R.S. The Role of Insulin Insensitivity and Hepatic Lipase in the Dyslipidaemia of Type 2 Diabetes. Diabet. Med. 1991, 8, 560-566. [CrossRef]

199. Lewis, G.F.; Murdoch, S.; Uffelman, K.; Naples, M.; Szeto, L.; Albers, A.; Adeli, K.; Brunzell, J.D. Hepatic lipase mRNA, protein, and plasma enzyme activity is increased in the insulin-resistant, fructose-fed Syrian golden hamster and is partially normalized by the insulin sensitizer rosiglitazone. Diabetes 2004, 53, 2893-2900. [CrossRef]

200. Drew, B.G.; Rye, K.-A.; Duffy, S.J.; Barter, P.; Kingwell, B.A. The emerging role of HDL in glucose metabolism. Nat. Rev. Endocrinol. 2012, 8, 237-245. [CrossRef]

201. Drew, B.G.; Duffy, S.J.; Formosa, M.F.; Natoli, A.K.; Henstridge, D.C.; Penfold, S.A.; Thomas, W.G.; Mukhamedova, N.; De Courten, B.; Forbes, J.M.; et al. High-Density Lipoprotein Modulates Glucose Metabolism in Patients With Type 2 Diabetes Mellitus. Circulation 2009, 119, 2103-2111. [CrossRef] 
202. Han, R.; Lai, R.; Ding, Q.; Wang, Z.; Luo, X.; Zhang, Y.; Cui, G.; He, J.; Liu, W.; Chen, Y. Apolipoprotein A-I stimulates AMP-activated protein kinase and improves glucose metabolism. Diabetologia 2007, 50, 1960-1968. [CrossRef]

203. Brunham, L.R.; Kruit, J.K.; Pape, T.D.; Timmins, J.M.; Reuwer, A.Q.; Vasanji, Z.; Marsh, B.J.; Rodrigues, B.; Johnson, J.D.; Parks, J.S.; et al. $\beta$-cell ABCA1 influences insulin secretion, glucose homeostasis and response to thiazolidinedione treatment. Nat. Med. 2007, 13, 340-347. [CrossRef]

204. Fryirs, M.A.; Barter, P.J.; Appavoo, M.; Tuch, B.E.; Tabet, F.; Heather, A.K.; Rye, K.-A. Effects of High-Density Lipoproteins on Pancreatic $\beta$-Cell Insulin Secretion. Arter. Thromb. Vasc. Biol. 2010, 30, 1642-1648. [CrossRef]

205. Fernandez, M.-L. Small HDL Particles Are Associated with Gestational Diabetes, Providing a Potential Early Identification Tool. J. Nutr. 2019, 150, 8-9. [CrossRef]

206. Mokkala, K.; Vahlberg, T.; Pellonperä, O.; Houttu, N.; Koivuniemi, E.; Laitinen, K. Distinct Metabolic Profile in Early Pregnancy of Overweight and Obese Women Developing Gestational Diabetes. J. Nutr. 2019, 150, 31-37. [CrossRef]

207. Sreckovic, I.; Birner-Gruenberger, R.; Besenboeck, C.; Miljkovic, M.; Stojakovic, T.; Scharnagl, H.; Marsche, G.; Lang, U.; KoturStevuljevic, J.; Jelic-Ivanovic, Z.; et al. Gestational diabetes mellitus modulates neonatal high-density lipoprotein composition and its functional heterogeneity. Biochim. Biophys. Acta (BBA) Mol. Cell Biol. Lipids 2014, 1841, 1619-1627. [CrossRef]

208. Mordwinkin, N.M.; Ouzounian, J.G.; Yedigarova, L.; Montoro, M.N.; Louie, S.G.; Rodgers, K.E. Alteration of endothelial function markers in women with gestational diabetes and their fetuses. J. Matern. Neonatal Med. 2012, 26, 507-512. [CrossRef]

209. Pasternak, Y.; Biron-Shental, T.; Ohana, M.; Einbinder, Y.; Arbib, N.; Benchetrit, S.; Zitman-Gal, T. Gestational Diabetes Type 2 : Variation in High-Density Lipoproteins Composition and Function. Int. J. Mol. Sci. 2020, 21, 6281. [CrossRef]

210. Brites, F.; Martin, M.; Guillas, I.; Kontush, A. Antioxidative activity of high-density lipoprotein (HDL): Mechanistic insights into potential clinical benefit. BBA Clin. 2017, 8, 66-77. [CrossRef] 